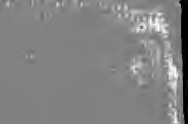




\section{UNIVERSITY OF CALIFORNIA AT LOS ANGELES}
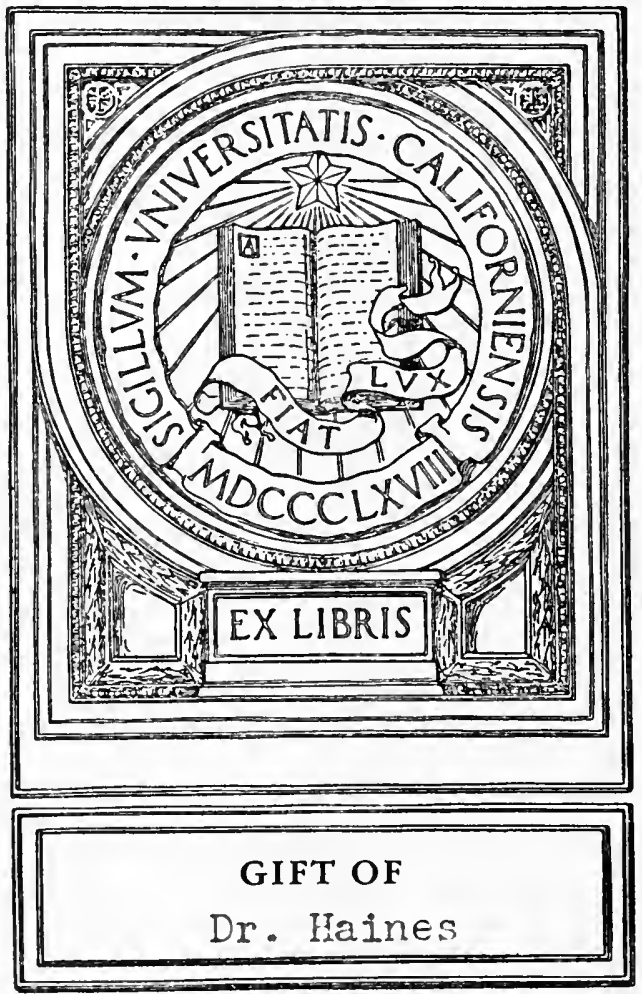
C. S. daines 


\section{Digitized by the Internet Archive in 2008 with funding from Microsoft Corporation}




\title{
Democracy's \\ International Law
}

$-\mathrm{BY}-$

\author{
Jackson H. Ralston
}

American Agent, Pious Fund Case, at the Hague, and Umpire Italian-Venezuelan Mixed Claims Commission: Author International Arbitral Law and Procedure; Editor Venezuelan Arbitrations of 1903, etc.

JOHN BXRNE \& CO.

Washington, D. C.

1922 


\section{Copyright, 192: \\ By JACKSON H. RALSTON \\ All rights reserved.}




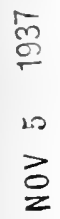

$\frac{4}{3}$

응
농
To

My Wife

SARA B. RANKIN RALSTON

Whose sympathies

have accompanied

the preparation of this wank. 



\section{TABLA OF CONTENTS}

\section{Chapter I}

How Findamental International Law is to be Discovered .................

Chapter II

Laws of War.................. 22

CHaptek III

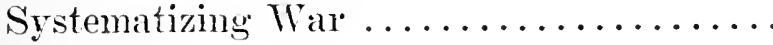

Chapter IV

International Sovereignty ...........

Chapter $\mathrm{V}$

The Meaning of "National Interests".....

Chapter VI

Superficiality of Today's International Law 57

Chapter VII

Imperialistic Adventure Under International

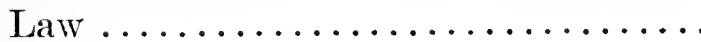

Chapter VIII

Deficiencies of Intermational Courts Under Present Conditions ............. 84

Chapter IX

Should any International Dispute be Reserved from Arbitration?.......... 102 
Cimapti:l: $\mathrm{X}$

Some Suplnsed Tust Causes of War...... 113

Chapter XI

Essentials of Peace and War........... 125

Chapter XII

Some 'lendencies Pressing Toward Justice amil Peace .................. 138

\section{Cirapies XIII}

Basis of a Democratic Law of Nations..... 147

Chapter XIV

Résumé of (Our Conclusions........... 159 


\section{F O R E W O R D}

Of late the very term "International Law" has fallen into disfavor. Men have felt that as now taught such supposed law had no fixity; that its assumed principles were only laid down to be flouted; that it was nerveless and without an animating soul; that it was but a paper creation. Yet it is the feeling of the writer that there does exist such a thing as true International Law; that its principles cannot be overlooked with impunity; that it moves with the silence and certainty of the law of gravitation; that, without having been written down, its violations bring punishment to all offending nations. The failure to read the secret of its existence and to study the lessons it would teach and profit by them, accounts for the prostrate world.

Something has been learned of the theory of Democratic Govermment. The little knowledge so accuired has been laid aside by writers on International Law as not pertinent to their purpose. In so doing they lave ignored the only way of learning true International Law-by tracing the consistent progress of Law from the small unit to the large. To point out this error; to indicate the manner in which the world's puzzle must be solved, is the purpose of this little book. It can not more 
than suggest a line of work for the future. Some such scheme of endeavor must be followed if we woukt apprehend the noblest branch of legal science yet to be examined critically by the human intellect.

Herein it is also sought to show how vitally the common man is affecter by International Law and his material dependence upon its understanding.

In the past we have been but charlatans, and have formotten that "Swifty the charlatan goes. Is it rark? He trusts to his lantern. Slowly the Statesman, but safe, timing his feet by the stars."

The writer desires to express his appreciation of thonghtful aid received in the preparation of this book from Mr. Arthur Deerin Call, Secretary of the American Peace Society, and of valuable comments and suggestions from Mr. Charles Fr. Nesbit.

Jackson H. Ralston.

Washington, D. C.,

$$
\text { June, 19:2. }
$$




\title{
Democracy's International Law
}

\author{
CHAPTER I \\ HOW FUNDAMENTAL INTERNATIONAL LAW IS \\ TO BE DISCOVERED
}

Of late much has been said with regard to International Law and its teachings. We are sometimes told about a given proposition that Grotius says this; Pufendorf says that, and Oppenheim or Hall says the other, as if the mere asseveration by any man, however distinguished, that a certain thing is Intermational Law makes it such.

The International Law writers have not thought to examine the characteristics of law in general. They have not sought to discover real law through its natural manifestations as applied to international affairs. They have not distinguished between that which is fundamental and that which is merely incidental, between rules of law and mere rules of order. It may in truth be said that, after several centuries of repetitions of doctrines and multiplications of instances, no consistent theory of International Law laying down the norm toward which all things must work has yet been propounded. Much learning without actual thought hath made us mad, in several senses of the word, 
while failing to carry us far on the road to justice in international affairs which must be traveled by the human race if it is to profit by International Law.

International Law writers have, for instance, been obsessed with the idea that war is a natural condition as between nations, and that its laws are, or by right may be, laid down by the combatants, even to the injury of neutral nations The idea has governed them that war has existed with greater or less irequence since early in the history of organized societies; that it is a necessary evil; that it is not within the power of man to stay it, and that all we may hope to obtain is some mitigation of its cruelties and some trifling dimimntion in its recurrence.

If the internationalists har taken the position that war is ordinarily an outrageous and contemptible thing; that its existence is an entirely human roncern; that usually its aims are sordid and that its causes are ascertainable; that the duty of International Law is to discern its causes and as far as possible to remove them; that the germ is to be sought with the same careful, painstaking determination which physicians have deroted to the discovery of the yellow fever or typhoid germ, and that this is one of the proper functions of the In 
ternational Law student, then some little advancement might have been made.

We would scoff at the medical science which should say, "Te can not isolate the germ of smallpox; we can not prevent its transmission from one human being to another; we can not fortify the system against it, but we shall take great credit to ourselves if, in occasional instances, we can prevent the spread of the disease from the body to the face." Relatively speaking, nevertheless, the results up to the present time of the study of International Law have been scarcely more important. We felicitate ourselves because we have established Hague courts for the determination of questions about which nations, or rather the interests controlling nations, are comparatively indifferent; but we have reserved the right to go to war over things which the managing minority. have regarded as important, and when the great majority are persuaded that their patriotic interests are involved.

What principles should our study follow?

Some years ago a former United States Senator, in speaking upon the subject of Arbitration, in an address delivered before the American Society of International Law, said: "We have been told by an international tribunal that by International 
Law the conquering nation alone may fix the penalty to be paid by the defeated nation and that there is no principle known to that law which gives a third nation a right to object." This is doubtless a correct statement of what is called International Law; but it is not law. That which is fundamentally law is universal as to time and place. All else is no more than usage. All that can be truly said by the writers on the subject of International Law with regard to the practice above mentioned is that observation has shown that usually the conquering nation does prescribe a penalty to be paid by the defeated country. This is a statement of fact, not a principle of law. Let us assume that men have observed that when a robber in the pursuit of his profession knocks down a man he usually takes from him his purse. The fact would be clearly recognized, but would not be incorporated in the law of felony We shall note meanwhile that in the forum of arms, the felonious nation is quite as likely to be successful as the unoffending one.

On the shores of the Arctic Sea in the North of Siberia dwell tribes which kill their elders when they become helpless, and these aged ones expect this fate and, perhaps, they expect, further, to be eaten. The man who would say that by their law the aged are killed and anten would be guilty 
of a misuse of words. There is simply a usage of this kind. Assume that hunting and fishing are unusually good with a particular family, and that such family preserves instead of destroying and eating its ellers, could it he said that a haw bas been violater?--Scarcely. I nustom of that time and place would have been departed irom, but no essential hunan rights wouk have heen lost; rather the contrary.

Going sereral thousan? miles further south, we find among the Chinese a careful preservation of the old, coupled with the worship of ancestors. But if a man fails so to worship, he has riolated no law, and he receives only snch supernitura! pumishment as may afllict him.

At the time of the battle of Agincome. when a soldier of the English king cartured a member of the French nohility, the individual cantor held the individual captive as his personal prize and restored him to liberty upon payment of a suitable ransom. This was the usage of war, and with en- tire propriety, juilging by present day standards, might have been written down by the intermationalists of that time as a law of war. But no power compelled a British captor to insist on ransom, and no human right, or any human law, would have been violated if he had set his cantive free. 
In the time of which we speak and for long after, looting hy the soldiers was consirlered entirely proper. At the present time looting by gorermments at least is practiced. But no law ever gave a right of mivale or public loot. To say, therefore, that eitlier one is the product of law or permissible by law, is to do a violence to lansuage. All that caln be said is that men at war have varied their actions from century to century, and their actions as so varied have been in soine hegree nsages which one might expect to encounter in the progress of the disease called war.

fousider what law, measured by the natural sciences, and save as varied by human characteristics, really is. If we study the law of gravitation we shall conchnde that it possesses the element of invariability from century to century. We shall diseover that it operates miformly moler like conditions everywere. We perceive that it is inescapable. When challenged, it will assert itseli. The same might be said with regard to the principle of conservation of energy or any other of the great natural laws. We have detected these laws by heing in the first instance struck by events which have indicated an anterior cause, and, from the event or from a succession of events, we hare discovered what the canse must he. It has been macle as the astronomer who has established he- 
fore he has ocularly demonstrated the existence of a star. The verturbations of other stars hare pointed the way.

While we have not been arare of this, our examination of law in national society has been much the same. Unconscionsly we have worked back from results or events to law and then proclaimed and enforced it.

The internationalist, having before him numberless differences between nations, a vast amount of material from which, with careful study he could have deduced laws which harl been violated, has contented himself with writing down the ineidents attendant upon the violations. He has been no more than the man with the muckrake looking down to the earth, when above and around is the glorious light of day,

Assume as thoronghly detached an attitude of mind as may be possible, and for at least a brief period lay aside the prejudices and predilections to which you may have grown accustomed. For the purpose of the discussion be prepared to indulge in what is called "idealization": to project ourselves away from all the hampering surroundings of the present into a future where reason and justice may be presumed to reign. If we contend that this is too great an molertaking and herond human ability, then religion must be a failure 
since it asks no less than this. It is only by idealization that futme progress is made. Before he puts his pen to the drawing paper, the arehitect sees in his mind's eye the magnificent strueture the ereation of which he is to direct. The statesman, desirous of reform, visualizes the end to be gained and the good which will be incident to it before the law is drafted. The student of Intcrnational Law must in this wise gain eomprehension of the ends toward which he should move.

What must be the aim and end of International Law? Why should it exist at all? These questions may be asked even before we determine its essentials $\mathrm{r}^{\circ}$ the divisions which it must assume.

Within the limits of the State the end of law is, it may be said, to preserve order and insure justice between man and men and between the State and the individual. This is well expressed by the Preamble of the Constitution of the United States which says: "We, the people of the United, States, in order to *** establish justice, insure domestic tranquillity, : and seenre the blessings of liberty to ourselves and our posterity, ro," etc. Turning to International Law, we may believe that its purpose is to attain as botween the States of the workl what will closely coresponl to that comdition sought to be established nationally by the constitution of thic United 
States. If International Law departs from this purpose, it violates the intent of its existence.

In our present study we shall be assisted in the begimning by inquiring as to what law is and somewhat in detail as to its divisions and purposes.

It is a trite definition of law, justified by the observations of Blackstone, though not completely true, that it is a rule of action prescribed by a superior and which the inferior is bound to obey. commanding what is right and prohibiting what is wrong. But if we go further, sundry distinctions are to be made. There is a great mass of what we call law which, in the profounder sense of the term is not law at all, but merely accepted rules of convenience. In England vehicles approaching from opposite directions, pass each other to the left. In the United States they pass to the rigit (This is not to be called in any deep sense a rule of law, but is more allied to what in the case of a corporation, may be termed "a by-law.') In turning over the pages of our statute books we find certainly four-fifths of all the laws which are passed are rules of convenience. They do not command what is right and prohnit what is wrong. They lay down modes of action for indifferent things; things which, without interference with human rights, may be determined in any convenient way. This, for example is the case with 
laws affecting dercents, aiministration of estates, execution of wils, formation of conporations, forns and titles and powers of purticular courts and multitudinons ordinances which do not differ from them, in essential nature, in the respect of which we are now waking.

rhen we have a harge body of statutes giving to us what is called adjective law, also rules of action based on no absolute theory of right, although conducive to the goneral ends of order. These determine, by way of illustration, the mamner in which adninistrators sha!l be annointed and qualify; the methods by which they shall be held to aceountability; how and where suits shall be brought and what shall be the formis of pleadings; how the judgments of courts shall be enforced, or appeals taken to higher courts, ete. These ordinunces in turn do not command what is right or prohibit what is wrong in wny moral sense, but further the general necessities of society.

There remains yet to be considered what we may regard as real law, dealing with the absolute right of man, as expressed in the Declaration of Independence, to life, liberty, and the pursuit of happiness. The experience of mankind has shown that the indiridual must be regarded as possessed tertain frimary rights. We have been a long time in diverering them, but we have largely sue. 
ceeded, and they have been made manifest by the fact that when they have been denied, such denial has meant social disorder or even revolution. This fact betrays the existence of real law as distinguished from ordinary rules of action and adjective law of which we have spoken.

We must enlarge this branch of the discussion by reference to crimes against order. The experience of mankind has demonstrated that following the commission of certain acts confusion arises in society, and there is danger of its growth save in some way it may be checked. From this fact it has been determined that these things have violated a social law originally mexpressed. Thus we have found that the man who committed murder has himself infringed upon the orderly conduct of society by his direct act and has created vendettas and fends. Te have further inferred that the man who so far lost contro! of himself as to murder once, was likely if unrestrained to commit a similar offense on another occasion. Consequently we have found as a fact that the commission of murder is contrary to natural law. Conversely, if murder had brought about no social effects of a disagreeable character we would have been justified in believing that it was not forbidden by any natural law of society and that it should not be forbidden by any community made 
law. Precinely like the ply ician we trace back the discase to the violation of the law of nature, althongh on on lant the operation has been unconscions. In the donnain of morals our conception of this natural law is called conscience. In the domain of legislation we have sought to enfore sucb las by the threat of pminiment. The essenial thing is that when men assme a certain social relation the infringement of thes laws areates disorder. which, being recognized, is denounced by the formal law of the community.

In the mamer just illustrated, we shall discover that all the other law forbidting and punishing crime have arisen under similar "onditions except

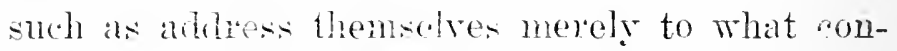
cerns the minor interests of the community, involving no numal elenent, and define mala pontibitit.

Haring fixer these listinctions, turn to the lield of Internatinnal an. Te diworer that ds betwoen States there haw been estabisher a great variety of "onventions. Nations agree among themselves on the formation of rules of navigation, treaties of naturalization, recognition of tralemarks and of copyrights, extradition, postal conventions, and an inmense number of minor "enventions: which involve no ahstract rigit as a rule, but ale the arrangenent of relations upon matters usually momally imlifferent. 
In each instance there is created a modus vivendi from which no one nation has any sufficient reason to depart. The rule is universally observed just as a like rule is followed within the State, and may lead to no material international differences. Aside from convention, there also grows up what may be called the minor common law of nations regulating their intercourse of courtesy. All of these matters are treated under the head of International Law and have their importance as the usages of polite international society.. In any profound sense they do not constitute law. They are simply usages or customs sometimes put in written form as being most convenient for reference, and when so placed least offensive to national susceptibilities. They should be clearly distinguished from fundamental law.

Like the rules within the state, we have a certain small body of International Adjective Law. Its most important expression is found in the Hague Treaties of Arbitration. It is further, however, to be discovered in connection with various of the conventions entered into between nations as relating to the manner of their enforcement. International Tribunals have to some degree developed such procedural law.

No reference is made to the so-called laws of war as part of International Law. They need not 
be treated as if they were integral law, in part for reasons already indicated. They are not certain as we have seen as to either time or place. They are not laid down by any superior and find none of their sanctions in the laws of nature or in the enforceable conclusions of international tribunals. They are not observed in practice except so far as the combatants choose to recognize them. Every attempt made to lay them down in an authoritative way has been as unavailing as would be the dictum of a physician to a man in fever that his temperature should not rise above a given figure. They much resemble an admonition to a man subject to paroxyms of insanity that wisen he is so attacked he must be sure not to kill anybody.

Having discovered substantial law within the State by tracing disorders back to the law the violation of which has caused the disorder, may we adopt the same process to discover the real principles of International Law and by endeavoring to secure their observance seek to remove disorders between nations? This process has received little attention from students of Interiational Law, and yet slight consideration will show that it is the method to be adopted if we are to obtain material results.

Why have we been so blind? It must be that when we look upon a State it seems so large, so 
peculiar, so absolutely in a class by itself, that we forget that it is lut a combination of indiriduals and that pari pessu the problem before us is not far different from what it was when we determined that the in!lividual shonld enjoy freely and without molestation, hut under conditions of order, his right to life, hinerty, and pursuit of happiness. We have imnored the fact that the State is but the indivinal grown large, and we have treated it as if we verily believed it was immune from the operation of the protective laws of lesser forms of Imman society. A mere glance at the teachings of history should have shown us our error and have convinced us that there were mderlying princip!es as strongly affecting States as affecting indiriduals, even though never written down in lawhooks and never enfored by fixed penalties.

Germany took from France the major part of Alsace-Lorraine. She deprived France of political control of the parts taken and gained for herself, or rather for some of her subjects, the advantages incident to the control of certain great natural resources. The privileges which in these respects France and Frenchmen had theretofore enjoyed were lost. The International Law as written in the books, which says that the victorious nation has a right to inflict its own penalties 
unon the loser, must justify the action of Germany. But the is a higher mrecognized Law of Nations, as thele was a higher law affecting slarery, which says that the thief of power and possession shall be pmished. Under this law, of which the hooks of learned authors take no cognizance, Germany, to protect her misdeeds, Wa. compelled to ambark mpon a career of intensified militirism. In its ultimate results the economy of the world was deranged. Her forcible theft was one of the great contributing causes bringing about the late war resulting in Germany's orerthrow.

Let us take another German instance illustratind the existence of fundamental Internationa! Law. Germany invaded Belgium in order to strike at France. In so doing, she broke an ancient treaty. Nore than this, she molertook to impose ler will upon a nationality not under her jurisdiction, and, upon resistence, enforced it by arms. That this experiment brought about such a reaction as was to be expected, needs no argument. Had it been alpuarently sucessful and enabled her to subdue France, we may believe that the consequences would nevertheless have been serions. No nation of the world would have trusted Germany. Other nations would have armed to the teeth against her, and her losses, 
though less immediately obvious, would have been no less certain.

We may infer from this the existence of an International Law which prohibits the invasion for selfish reasons of one country by another, even though we find nothing written upon the subject. Nevertheless action and reaction are equal, and the results are inescapable.

Great Britain, in her manner of treatment of her American Colonies in the 18th Century, imposed her will wrongfully in many different ways. The reply to her action was the American Revolution, and she lost a Continent. Rendered wiser by experience and knowledge, she since that time has largely avoided her former errors. Again we are taught real International Law.

Turn to another instance where the story has only in part been told, and the developments of which lie largely in the future. Various nations have taken advantage of the military helplessness of China and have undertaken to seize for themselves ports and for their subjects concessions. They have infringed mpon her national independence. They have apportioned to themselves spheres of infuence. They have established consortiums to regularize enforced control over railways and other profitable undertakings. Have these repeated riolations of right brought with 
them a sense of security or eren financial benefit to the nations concerned? The answer clearly must be "no." The further the nations have penetrated into China the larger have grown their military and naval expenditures; their jealousies of each other; their fears of the result to themselves if ever the Chinese giant rakes up. Even today the balance-sheet by any proper reckoning would show a physical, and, as it undoubtedly does, show a moral loss. He who would read the future can see that these losses are manifestly capable of tremendous expansion.

The several nations in ('hina have thus taken steps inmoral (unlawful) in themselves and involving punishment. Can we not therefore infer that the nations have violated a natural International Law of Nations, the punishment for which violation is absolutely certain?

One is reminded of the story of a consultation between leading Chinese disturbed over the situation when the Manchus seized the government of China. When they were gathered together one of the most respected of them was called upon for his opinion. He said in substance: "We need not disturb ourselves. The Manchus will be swallowed my by the great body of Chinese; their porer will ebb away from them, and in 200 years we will not know that they ever existed to trouble 
us." These were the words of a philosopher who recognized that time is not alone of today, but belongs to the future as well. We shall not have to wait, and we are not waiting 200 years for the evolution of events to bring about the reward for ills inflicted upon China. We live in a world moving more rapidly. The essential point is that the punishment fits the crime, and the punishment connotes the crime.

The will not ignore the fact that nations have been bronght into their present condition of relative solidarity through innumerable wars, crimes, and injustices; but this fact will not answer our main proposition. Had mankind been less stuvid; had it delivered itself orer to thought rather than to action; to reason rather than to blows, the advancement might have been many times more rapid and the continual setbacks caused by revenge for wrong, would have been avoided. Only now we have an illustration of this rery pount. Five months of tactful discussion have done more to insure peace and real amity between the English and Irish than has been accomplished by five centuries of $\mathrm{Tr}$ rong and war.

Te must not forget that the essential evils of a given line of conduct will not stand ont with equal prominence in all stages of human development. As the scale of civilization rises; as 
social development takes place, it is found that things which were socially wrong when the units were small, rise into new prominence and impress the onlooker as of old the error would not. Nurder and robbery are events of less significance, we can thus understand, in a rude society than in one of fuller development. To use an illustration from the economic world, we may take the rule finding frequent illustration in our State Constitutions of $100 \mathrm{or}$ more year's ago, requiring all forms of property, real or personal, to be subjected to the same tax for the benefit of the state. In a condition of even distribution of wealth where, roughly speaking, each citizen possessed relatively the same proportion of real and personal property and absolutely no great wealth at all, the evils of this economic blunder were not manifested, but later they were easily perceived. We may properly argue that the same conditions apply to nations; that in their earlier and ruder development, (and after all States in the modern sense of the ter'm are not historically old,) the revulsions caused by violations of natural law appropriate to States were not pronounced. Of late, however, with the rapid development of States as the representatives of worldwide civilized society, and with their closer association resultant upon growing facility of communication, and the superior 
intelligence of their citizens, the evils which were localized or small in the begimning have gained a widespread character and carry with them frimitful results.

We have been multiplying experiences of late, piling one upon another, until standing at their top we are enabled to discern much more than the beginnings of a real International Law. If mankind had reached a stage of theoretical perfection of apprehension, its appreciation of the laws of in. ternational society and of the certainty of auto. matic punishment for their violation would be sulficient. No formal laws would be necessary. But such a stage has not been reached. Nations need the admonition which will be expressed in formal International Law when it shall come to be written. For the individual we find that, largely because of his deficiency in imagination, punishment is necessary, and also that prevention has its proper field. In the Law of Nations we shall likewise have the three stages, admonition, prevention, and punishment. Usually admonition when once written into law will be sufficient. Then it fails prevention in various forms will bring relief, and immediate punishment will often carry more conviction than the slower process of natural law. 


\section{CHAPTER II}

\section{LAWS OF WAR}

1 chemistry from time to time we find two vastIy different substances which, on analysis, must be described by the same formula. Nevertheless there exists between them subtle but substantial differences defying analysis. Were we to give them the same name because of apparent ehemical identity we would be involved in endless confusion and led into impossible situations.

This confusion, aroided by the chemist, exists in the realm of international matters. We speak of international jurisprudence as being divided into the latws of war and the laws of peace. Te are deceived by the fact that in each instance usage lies in the background. We find many propositions in both illustrated by treaties, and in certain phases, relatively minor as to war, we discover that resort is had to conrts of restricted jurisdiction which profess to lay down rules of artion. Becanse of these apparent unities we deceive ourselves and use the same word to represent illeas entirely in dissonance. The discover atomic mits whose similarities deceive us but by which in like cases the chemist refuses to be deeeiver, and we worship names bestowed because of apparent likeness. The life of the spirit is ig- 
nored. It is much as if because of resemblances we were to insist that the Cardiff giant and the Frankenstein monster were men.

Law, writers tell us, is a rule of action laid down by a superior and which the inferior is bound to obey. Sometimes we are told that it commands what is right and prohibits what is wrong. There are legalists who transpose this to mean that what it commands is right and what it prohibits is wrong. At least, law is supposed to be based on the morally right and to be bounded by reason. Furthermore, it is presumed to be certain-not to be set aside or raried by the whims of the individual without regard to the effect of his action upon others. Again, it is capable of enforcement. (Of course, we are dealing broadly with substantive law in its important aspects, and only touching in a small way upon legal rules of convenience or of procedure, which are beside the present argument.) In a sense, the rast body of law may be said to grow out of usage and custom; but all customs are not law. The custom of slaying and eating enemies taken in war may have been very general for thousands of years, but never rose to the dignity of law, howerer toothsome, satisfying, and economical the practice inay have been. The custom of the victor in war to take from the ranquished life, liberty, and terri- 
tory, or to enslave him by debt, is nothing but a display of brute force, and not law and not sanetioned by law.

We may believe that in their peaceful relations there is a law between nations capable of natural and righteous development. It is based upon reason and humanity; it has a backing of right; it recognizes that intercourse between nations should approximate such as exists between gentlemen. When it is fully developed in all its phases, it will prohibit one nation from taking advantage of another simply because it has the power to do so. It will recognize the indecency of a nation trring to elevate its nationals at the expense of the wellbeing of the citizens of other nations. Its ultimate end will be the application of as severe and perfect a justice between nations as our defective humanity will permit to exist betreen individuals. It will be the outgrowth of custom, in so far as custom is based upon ethical principle, and will find expression in treaties, the studies of writers of eminence and the utterances of jurists anthoritatively placed.

Our national law concerns itself with the promotion of justice between man and man within the State. The mit of International Law will be a nation and not an individual, and its purposes will be to preserve justice between nations. This, it 
will finally discover, can best be accomplished by following the highest ethics of which we will be able to conceive. Such will be the International Law of the future, but it will be a law absolutely and entirely based upon justice. It will understand that ideal peace excludes international economic conflicts and is not limited to the rude clash of physical ar'ms.

With this ideal of law we have confused what we wrongly call the laws of war. These so-called laws offer no moral considerations whatever. They rest necessarily upon destroying human lives in such manner as will entail the greatest advantage and the least comeback to the destroyers. For the latter reason particularly prisoner's are not ordinarily killed. The retaliation might be unduly severe. The prime duty of a nation in the time of war is, we are told, to render the opposing nation helpless and force it to bow to superior strength. Any act to this end is moral and justifiable, as is thought by the perpetrators.

Adrancement in developing the supposed laws of war is curious. We no longer torture a captive and eat him, food being more abundant. Te burn him alive by flame-throwers or consume his flesh by gas. We argue among ourselves as to the comparative humanity of tearing a man to pieces by shrapnel or suffocating him. We are shocked by 
the conduct of the Indian who with a blow-gun propels a poisoned arrow toward his enemy, and we do not condemn the firing of shell which in exploding scatter about poisonous and destructive vapors. We eren make in Hague Conventions and otherwise solemn resolutions as to what methods shall be followed and then do as we please, because our resolutions have no basis in reason; do not adrance the cause of humanity; are incapable of enforcement, and present nothing of the spirit of law, although we give them the high-sounding title, "laws of war."

The have deceived ourselves by the use of an inappropriate word. Our analysis has shown superficial, and even structural, resemblances between the laws of peace and the usages and customs of war, and with a complete lack of discrimination the subtler things of the spirit have eluded us.

Time and again we have been told that International Law has been broken during the recent war until the very name is a mockery. This is true only in the same sense that the word as applied to the customs of war was a mockery before the second of August, 1914. The hollowness of these customs as furnishing law, in any sense of the word, has been exposed by recent happenings. if we do but consider the matter with ordinary care.

Heary tomes have been written about riolations 
of International Law in the late war. Cities have been bombarded without notice; hostages exacted and slain; peaceful merchantmen sunk withont warning, and a rast category of events occurred, forbidden according to supposed authorities and against the resolutions (improperly dignified as conventions) of Hague Conferences; Allies or Central Powers have been reproached, though they have but simply followed the ancient truth that men frantically mad have no conscience. Te have forgotten that as long as we admit the propriety of outbursts of war we camnot place limits upon its manifestations.

And yet, to illustrate, real principles of International Law were violated when Germany invaded Belgium to attack France. It was as if two neighbors, separated by the land of a third, had gotten into a quarrel, and one had torn down the intervening fence and destroyed the property of the third to attack his enemy in the rear. Still we may not denounce this act too severely. Germany was doing what she thought necessary for her success, treaty or no treaty. She was strictly iollowing the teachings of the great god Mars, and doing in a new way what in principle war for centuries has permitted. As a combatant she was laying down her own rules of conduct toward a neutral. 
The invasion of Belgium was a little more or a little less of an infraction of the rights of an innocent nation thin is a blockade. The latter prohibits the neutral who is not concerned in the quarrel from trading with the blockaded ports. The will of the country which has kept its hear? is subjected to the will of the mad nation. The essential wrong of the act of Cermany in entering Belgimm was not that she broke her undertaking to observe the nentrality of Belgimm, but that she cntered Belgimm at all, the entry withont leave being a riolation of Belgium's right to control her own life.

Once we admit the rightinulness of war and the power of 'ombatants to lay down their own rules of action to control nentrals, we cut from under us any ground of complaint of casnal invasions of the territory of neutrals, such invasions being merely a llarticular form of disregard for the rights of other's. We should not complain of the forma of the act, but of the fundamental wrongful conception.

This review may in some degree, let us hope, serve to call attention to the fact that the so-called laws of war are not laws; that they should not be so treated, and that if we would be on the side of the future we must recognize the customs of war as heing violative, in practically all of their forms, of national and individual right, and therefore beyond the pale of legality. 


\section{CHAPTER III \\ SISTHIATIZING WAR}

"Of lan there can be no less achowledged than that her seat is the bosom of God, her voice the harmony of the world: all things in heaven and earth do ber homage, the very least as feeling her care and the greatest as not exempred from her power; both angels and mon and creatures of what condition soever, though each in linerent sort and manner, yet ail with wnform consent, admiring her as the mother of their peace and joy.'

Accepting the spirit of these lines, written by Bishop Hooker in his Ecclesiastical Polity some three centuries ago, we may believe that when men first discussed the "laws of war" Wars chuckled, and since that time high Olympus has resounded with his guffaws. Laws of war, what are they? What are the laws of arson? The iaws of mayhem? The laws of murder? Can there be laws of lawlessness? If so, where do we find their sanction? Who created them? Tho will enforce them? Are their roots found deep in moral principle? Are they the result of natural perception and logical development? Who welcomed them as "the mother of their peace and joy?"

When we accept these laws we bow to the rule of orderly disorder, moral immorality, justly and equitably planned disregard of human right to life, liberty, and the pursuit of happiness.

After all, these laws strangely mystify us. We 
find that they may be disobeyed without penalty or punishment. Te discover that under their rule it is righteous for an army to explode mines under the feet of an unsuspecting man; it is unrighteous to use false flags. It is proper for a submarine, like a midnight assassin, to blow up a vessel of war; it is improper that a peaceful merchantman, to escape destruction, should fly the flag of a foreign nation. One series of deceptive acts may be condemned nuder the laws of war, and another may be sustained; and when we seek for a rule of reason we find we are, as it were, on a shoreless sea, without a rudder, with no compass to guide us, and no sail to carry us to a port of safety.

Perchance there may be some deep fundamental error in our attitnde toward the subject. It may he that somewhere we have missed our bearings, for we are continually calling for aid from the laws of war and getting only Delphic response.

What is the error of which we are guilty and at which Mars scoffs? We have treated war as a legitimate thing, with regard to which consistent laws might be laid down which would enforce themselves. Nationally, we have laws against mayhem, arson, murder. Internationally, we accept these things as just. We have no laws 
against them. The have so-called laws of them. When we have met in Hagne Peace Conferences, as in 1907, we have passed six times as many Conventions concerning the warlike relations of States as we have concerning their peaceful relations, so legitimate is war. Te never proscribe it, limit it, punish it.

If we could imagine a country in which the inhabitants expeeted sooner or later to indulge in marauding against one another and seizing each other's property for their several uses, then we could further imagine these same people getting. together in solemn conclave, as our nations do, and piously resolving that as individuals they would not raid one another save when they personally felt that they had been insulted by their fellors, or save when their important vital interests, as they individually determined them to be, demanded that they possess themselves of the property of each other, and then only under fixed rules, as, for instance, that while they might kill the head of the family, they would not lill children under the age of six; that they would not make slaves of the survivors, but only take away their property or mortgage their labor for future years; that they wonld endearor to nurse back to health those of their neighbors whom they wounded but failed to kill at the first shot. These 
law woula be reasonable, as reasonable as the laws of war, and yet perhaps we would all admit that there might be circumstances of convenience and advantage, and perhaps of humanity, or even morality, which would prevent the entry by individuals into such contracts.

Turning, however', to the Law of Nations, we say in Hague Conventions that states may themselves judge when they are insulted, or when their vital interests demand that they should be their own executioner's. Haring so declared, we next lay down rules of action to apply when they are at war, but without reserving power to enforce such rules. In themselves the rules may be as excellent as was the rule of action governing Robin Hood, when he stole from the rich to give to the poor. England frowned upon his exercise of this principle, but other nations, and England as well, have never dissented from the idea that it was entirely proper to extend the blessings of civilization over far countries under cover of camnon smoke, or that the rich and powerful nations should take from the poor and weak

Our laws of war have ntterly failed because they have started from the premise above indicated, that war was natural, ineritable, even laudable and righteous. Te can never meet the difficulty until we approach the problem from an 
entirely different standpoint. We must, as a nation, treat war as abhorrent and to be stamped out. We must nerer again send a representative to a Peace Conference to write the laws of war. In the place of such burlesque upon peace, real declarations of principle must be written by nations indulging in it. At least nations must do this and accept the consequences of such new rules of action if, indeed, they believe war to be an evil and a nuisance, though they think it may fall short of being a crime.

It makes a great difference whether the laws of burglary are framed by burglars, even by those who, recognizing the frailty of human nature, expect that some time or other they will be compelled to resort to burglary, or, on the other hand, by citizens who are not burglars, do not expect to indulge in burglary, and do propose to treat it as an objectionable occupation.

To give slight concrete illustrations of the idea we have in mind, we may call attention to the fact that one of the Hague Conferences undertook to regulate the use of submarine mines in war. This recognized the legitimacy of their employment. Again, according to the accepted practice among nations, a city may be bombarded and the property of neutrals destroyed, and such neutrals are without recourse. Approaching 
these topies from a saner point of view, we would agree that a nation which, by planting mines or through any other act of war, inflicted injury upon the property of the individuals of a neutral nation should be responsible for the injury inflicted.

To illustrate: If, gun in hand, and endeavoring to kill my enemy, by mischance I slay an innocent bystander, I am punished for the act; the fact that my aim was had will not excuse me. Even civilly I may he compelled to pay heavy damages to his wife and family. If $\mathrm{I}$ set a trap for an enemy, and by accident kill a friend, our municipal laws hold me deserving of punishment. The nation committing like acts should receive corresponding punishment.

We should not allow any nation to gain material advantage, or assumed material advantage, as the result of war with another nation. If, in a dispute, I am overcome by another man, he gains no right to hold me down until I yield to him my purse or deed him my property. Yet we are told that by the laws of war similar acts may occur between nations and be fully justified. We may truly say there are no such laws of war-that in such things are lacking all the elements of law, whether measured by the criterion so eloquently stated by Hooker or by any criterion recognized 
among men who clain a speaking acquaintance with the Ten Commandments or with the proprieties recognized as existing among gentlemen. If a thousand times men have been overcome by their enemies and despoiled of their pocket-books, there is not thereby created a law of robbery. A thousand like instances as between nations cannot create a law of war sanctioning such conduct. The fact that under given circumstances men or nations have taken adrantage of one another does not create a law of wrongdoing, but only indicates a tendency on their part, their passions being excited, to ignore the laws of decency.

We will further add to our national laws. Within our borders we will prohibit the flotation of bonds to carry on war, just as we punish a man as accessory to a crime who loans money to another to buy a gun to kill his fellow. Likewise we will prohibit the selling of arms and ammunition by our citizens to another nation to carry on war, for in so doing we make ourselves accessories to the ensuing slaughter. We must have our own rules of righteousness and right living.

We will make it more difficult for ourselves to enter into war. Today our congress and our President may declare war withont real knowledge of popular sentiment, influenced by the excitement of the moment, and we are compelled to 
follow in their train. Te will prevent declarations of war before in some manner the question has been submitted to the cool judgment of the people, and if this be done we may be assured that we will never enter into them. War has ever been a game for kings to play at, and Presidents and Congresses should not suceed to their role.

But if our thesis be wrong-if we must continue to have laws of war instead of laws against war-let us address ourselves to the problem in a sportsmanlike way, and let war be a game, sanctioned as such, and carried out under enforceable rules. Let us be systematic, forming a circle around the combatants, and allowing no nation to trade with them while the game proceeds. Let the prize be determined in advance of the conflict, so that each nation may know exactly the penalty of defeat or the reward of victory. Let strict rules be established, with an umpire furnished with power to call the game off, enforce forfeitures, or adjudge victory to the side winning the most points or indulging in the fewest fouls. The burning of a town should have a fixed value; the killing of a thousand soldiers, the slaughter of civilians and the hombardment of unfortified ports, the sinking of an eneny's ship_ressel of war or merchantman - should be rewarded, and a proper number of points allowed. So many points should be de- 
ducted for the destruction of the ressel of a neutral nation or the killing of neutrals. Of comrse official tally-keepers should be appointed.

In this or some similar way it will be possible to systematize war as we do a baseball contest or a game of parlor bridge, and thereby add to its sanctity and glory. 


\section{CHAPTER IV}

\section{INTERNATIONAT, SOVEREIGNTY}

In our studies of war we very largely neglect consideration of the bases of what is called International Law. If we give attention to the subject of murder we take into aceount its morality and motives, the manner and circumstances of its execution, moral and plysical sanetions or punishments, and from them all we huild up the theory which on its practical side should be embodied into permanent law. Not so have we approached the great problem of world trouble, and yet such like methor? of treatment would give a rich rewarel.

A few preliminary observations may be made before we consider what is meant by the term Sorereignty, the subject of our present examination. International Law hooks are filled with doctrines founded non instances which, when matched against each other, are said to create law. This is done without relation to or consideration of underlying prineiple. This, if studied, might learl to widely different results. No endeavor is made to discover what real law is hy going backwarl from event to logical cause. There are few Newtons among the students. A fallen apple at most is simply an apple fallen, and it is put in the 
barrel with its fellows, whether green, ripe, or rotten. All deductive reasoning, however valid, is rejected. Such synthetic reasoning as is indulged in rests mpon the naked earth and is built up without the mortar of sympathy, ethies, or any real theory. Facts are rough hewn and laid one upon another without, to follow the metaphor, heing coursed or bonded. The laws of war we discover to be merely usages modified from age to age according to the kind of serere or moderate cruelty popular at the moment.

The remarks so far indulged in, as we may be confident, will be justified in part at least by the special consideration to be given to the meaning and application of the word "sovereignty." With this word practically all writers of International Law books introduce their volumes, and never do they give it and its applications practical analysis.

"Sovereign power," says Grotius, "is one whose acts are independent of any other superior power, so that they may not be annulled by any other human will.",

Says Oppenheim: "Sovereignty is supreme anthority; an anthority which is independent of any other earthly power. Sovereignty, in the strict and narrowest term, includes, therefore, indepen- 
dence of all round, within, and without the borders of a country."

What anses sovercignty? Who created it? By what authority does it deny existence, actual or potential, to any superior outside power? These questions are not answered. The definition is an assumption. As well might the bully anong school boys say, "I am sovereign. I am not accountable to my fellows. I shall treat them as I see fit. I shall control my own actions without limits and without restraint. I shall undertake to supervise the conduct of any other person if I so choose." This declaration might work rery well for him until he met a stronger bully or until two or more of the weaker boys combined to thrish him. Under these cireumstances he would find his sovereignty infringed upon, suspended or destroyed. If these erentualities may happen, he does not possess sorereignty. It is merely a figment of the imagination which may not prevail against stern realities.

These are exactly the conditions we observe between nations. The nation afflicted with a prepossession of its own sovereignty, carries on, according to Grotius or according to Oppenheim, until, like the school boy, it meets with a superior bully or a stronger combination, and then, for the time being at least, sovereignty bows its head. Sov- 
ereignty therefore is not an absolute quality of nations and the definition fails, never having had any firm foundation.

All that International Law offer's is an anarchistic conception of sovereignty as its basis. The individual who owes no deference to law or to his fellows, or at least acknowledges none, is at best an anarchist or at worst a king.

We are not compelled to acknowledge the correctness of the theory of an original social contract to be convinced that men living in civilized society must, for their own good and to meet the necessities of that society, submit to laws designed for mutual protection. Strange to say, when the international lanyer envisages a State, he forgets that a State is but the individual grown large, and that right and wrong have no relation to size or numbers. There must be and there is a reason for this. Accepted International Law from its beginnings has been, for the most part, the outgivings of diplomats. These gentlemen have been reared in the atmosphere of courts wherein they were taught that their masters, the kings, could do no mrong. They, inaugurating the Law of Nations, have felt

"the force of temporal power, The attribute to awe and majesty, Wherein doth sit the dread and fear of kings." 
There wis no step between the king, the Lord's anointed, and Deity itself. By a natural sequence this idea was applied to the State.

Few real lawrers, trained in the admeasurement of human rights in contests developing the fundamentals of buman liberty, have examined the sonrces of bookish International Liw and tested its conclusions. The professors calling themselves internationalists have accepted the teachings of the diplomatic world. Thus it has been that the definitions of sovereignty we have quoted have met aequiescence. It has been forgotten that sovereignty may only be postulated upon the superior power of the State over its inferior components. Eren then limitations control it, but these we need not outline. They have been sufficiently discussed by Sir Henry Maine in Early History of Institutions.

Let us consider. As between the collective will of the State and the will of the individual, that of the State must be supreme, else the State perishes and civilization may fall. Exaggerated dread of such failnre accounts for the severity of laws against anarchists, often going so far that they would even stifle freedom of speech.

A State is formed by licit or illicit means. It comes into a world peopled by other States, each one riaiming sorereignty as against its fellows. 
Each is influenced by the prepossession that it can do no wrong and as covereign is bound to its fellows by no ties of morality, justice, or law. It is serenely mmoral. From the absolute logic of this position it is compelled to recede somewhat, as would a group of anarehists on a narrow island. It establishes treaties, which it breaks whenever it is pleased to do so, for a bastard International Law has declared its sovereign right to do wrong as it will. This anarchistic concept controls it. That disorder forbidden to the individual it inculges in on its own behalf when in the society of those whom after all International Law is often required to call equals. And International Law ignores the fact that among equals none is sovereign, and that such a thing can only exist by the common creation of all the equals. If a State makes a treaty it acts merely as sovereign orer its inferiors. It remains not more than an equal among equals who should be able to hold it to accountability. It is, therefore, not true as Oppenheim implies that a State can be sovereign beyond the borders of its comtry. Attempting it, international anarchy results, one of the worst illustrations of this anarehy being the recent world war.

Real sovereignty ceases at the country's limits. The right of the householder to impress his will 
11)on another without his consent ends when he passes out orer his threshold. Kings, flattered by their courtiers, have denied this. Diplomats, their serrants, have echoed the denial. Internationalists have weaky followed in their train. Confused by a name, appropriate enough for limited home use, given a wrongful extension beyond the lome of the nation, men have perished by millions in foreign wars.

It is not inapt to compare the game played by nations in their interourse with each other to that of rival school boy baseball teams. With regarel to his own affair's strictly, each boy ordinarily has a right to control his actions. When he enters the haseball nine, he becomes subject to fixed and certain rules, and if he continually violate them, his fellows or certainly the umpire will expel him from the game, expulsion being an appropriate punishment. By his entry into the team he has circumscribed his liberty in certain respects. He has made himself subject to law and to the execution of law.

The action of the nation entering into the family of nations should not be different. Imperative rules are yet to he made for this world game. A disinterested umpire must see to the infliction of no less a penalty in serious cases than that of temporary or permanent exclusion from 
the society of mations. His jurisdiction must also be preventive. All this does not involve, as will result from what has already been said, the surrender of domestic sorereignty, the only kind logically permissible. It simply involves the recognition of that equality among the nations before the law which we say exists among the people, and, as pointed out, sorereignty and equality are incompatible terms within the same sphere of action.

The nation which is more than a hermit as was Japan prior to Commodorer Perry's visit in 1853, is, whether it will or not, subject to the domination of law, if not of expressed laws, in its relations with its fellows. To its actions there are appropriate reactions carrying with them their meed of reward or punishment, even though written or unwritten formal International Law be silent. These are as inescapable as the law of gravity. This would not be so were nations in truth sorereign in their foreign relations.

We enter into postal, copyright, white slave, navigation, and a score of other conventions regulating our interests with equal nations. We observe them with scarcely a deriation. These are the laws of equals, no one claiming extraterritorial sovereignty when they are entered into. The national government in making them is simply the agent of the whole bodr of citizenship. 
But certain classes of conventions we look upon askance. When we are asked to enter into treaties which would restrict on pride, our ambitions, our lishonesty, our covetomsness, wis discover that the nation is a sovereign and can brook no superior. We are blind to the fact that such proposed treaties would do no more than check wrongdoing or regularize its punishment. We think that by refusing to form them we escape punishment, forgetting that wrongful action nationally brings in its train jealonsies, enmities, distrust, loss of trade and-war. Our devotion to a word. blinds us to realities. 


\section{('HAPTER V}

THE MEANING OF "NATIONAL INTERESTS"

In our study of International Law as understood and practiced today it becomes interesting to learn exactly what so-called "national interests" mean, and why and how they may be used to bring about difficulties between nations. A thorough diagnosis of the situation and its fearless treatment would go far toward inangurating correction of present conditions.

The European viewpoint was stated by Von Jagow, the former German Secretary of State for Foreign Affairs, in his comment upon the Lichnowsky Memoirs, published toward the end of the war. He said "Even Prince Lichnowsky does not deny that we had there (in the Orient) great economic interests to represent; but today economic interests are no longer to be separated from political interests.',

This represents the old, and, as we might have hoped, the dying conception. Its suggestion is, first, get hold of a country through its economic interests, and next, control its political interests for the benefit of the economic. This has been the order of the day largely in the past--- changed

* From the Adrocate of Peace, December, 1921. 
only by reversing the sequence and seizing political control with the intent of using such control to derelop economic profits.

Nevertheless, we find Sir Edward Grey and Prince Lichnowsky proceeding on behalf of their respective govermments to divide up parts of the world as the larger interests of individuals of their respective countries might dictate, with the supreme thought in their minds that if a suitable division of economic control of the comtries in question should be made, the chance of armed strife could proportionately be eliminated. This very position was in itself a confession that the great danger of war between the two nations was in the desire of goreruments to seek for groups of capitalists new fields of exploitation.

We learn with interest that "all the economic questions connected with the German enterprise were regulated in substantial accord with the desires of the German Bank." It is hard to conceive in this dar, when the rights of the common people are assumed to be paramount, that in determining a question of possible war or peace a settlement should be controlled by the wishes of a bank.

Further, we find from the same Memoirs that the Germans were to be admitted by the treaty arranged between Sir Edward Grey and Prince 
Lichnowsky but never actually ratified, "to participation in Basra Harbor Works," and that they were given rights in the Tigris which had formerly been a monopoly of the firm of Lynch. The Prince finds that under this treaty Mesopotamia, as far as Basra, was to be a German sphere of interest without prejudice to certain older British private rights, while British were to control the coasts of the Persian Gulf and SmyrnaAidin line, the French, Syria, and the Russians, Armenia.

It is said often that European nations have, or have had, spheres of influence in China, Africa, and elsewhere, and that within these spheres of influence their national interests were entitled to full play at the expense of other nations. Japan, we are informed, las special interests in China (the Lansing-Ishii notes erroneously declared them to exist) and Spain and France are now claiming them in Morocco.

Can a nation, in point of fact, have any interest in a country over which it does not possess perfect and complete sovereignty? We must deny it. The purpose for which government is formed is not to have, as a government, interests in other countries. It is formed for the preservation of order and the regulation of internal affairs within its own circumscribed limits and for pro- 
tection against invasion. It does not control the railroads, banks, ore heds, or commerce of another country, and ordinarily its scope of operations in these respects is very limited, even within its own proper territorial bounds. It may happen that a large number of persons of Japanese, English, or other origin may orn and manage railroalds, mining property, and banks, and carry on commerce in China or elsewhere; but the things which they own are private, or so treated, and individually possessed by them because of the good grace of the country in which they happen to operate. Their possession becomes a source of profit to the owner, the only govermmental interest of whose country is through the small measure in which such owners become contributor's to its taxes.

The so-called British or Japanese interests in China rest in the keeping of a few hundred or a few thousand individuals. The great mass of millions of other subjects derive no profit or benefit therefrom. It may not, therefore, be said in any true sense of the term, that there are British interests or Japanese interests in China or American interests in Mexico. 'To speak of the interest of an American ritizen as if it were the same as an American interest, or in other words, an interest of America, has but the shadow of truth 
and none of its substance. We shall not be free from the danger of war until this fact is thoroughly unlerstood. We should not allow omselves to he deceived. We must not treat the hand of Esam and the roice of Jacoh as if they belonged properly together.

There is but one interest which may by any possibility be called governmental (in truth it is not a govermmental, but a world interest), and that is that, commercially, all foreigners within a country should be treated upon a basis of equality and not of preference. This was al! that mas inrolved in the so-called open-door policy of the late Secretary Hay. To go to war, howerer", to establish an open-door policy would simply mean the infliction of misery upon thousands for the benefit of the handful who would be the principal gainers therefrom. The evil would always be certain; the good problematical and doubtful. and at best out of all proportion compared with the absolute disaster.

But if we are right, and we do not think the positions so far taken can he successfully controverted, why is it that psendo-national interests are so often at the bottom of ill-feeling between countries and, as in the latest workd tragedy, the underlying cause of active wir? The short answer some might find by recalling the re- 
mark of Carlyle one humdred years ago that England was inhahited by 20 millions of people, mostly tools. The people of all countries are deluded by a word. A few of their number desire special ndrantages in designated comntries, and, forgetting their porerty and real non-interest, the majority believe that they may share in the profit which goes only to the fer.

We have heard, as who has not, the campaign orator describing to a credulons audience the tremendous adrance in popular prosperity which had occurred mier the then control of his party. Billions have been spoken of as if the speaker and his hearers really understood and comprehended the word in its full sense. Millions seemed in be dancing in the air as the audience subjected itself to the hypnotic influence of the orator. The illusion of great wealth took possession of the hearers. And yet, when the voice of the orator wals stilled, the band had ceased to play, and the lights were turned out, the poor listener's went to their homes to struggle with the same poverty they had always experienced. The billions were somewhere, but not with them.

In like manner nations are befooled by the limiter number who hope to gain through the possession of foreign wealth. Insistently the people ale told, and in a state of hypnosis they believe, 
that in some mysterions manner the dancing ignis fatuus of foreign fortune is to be converted io their individnal use. Thus it was that the Freneir common people were persnaded to give up then: lives and fortunes to conquer Mradagascar and Tonquin, and the Italian peasantry taught that they were to grow great and wealthy throagin the control of Tripoli by their government. Eren in our own comntry, when the taking of the Philippine Islands was under consideration, anxious official inquiry was made as to their potentiality of wealth, to the end of satisfying the American people when about to enter upon an experiment which many of them regarded as douhtful.

Perhaps, after all, the error of the many is only a survival, as the coceyx and the vermiform appendix are supposed to be. When a tribe moved of old from an inclement or worn-out land and seized a mild and fertile comntry, killing the old inhabitants, each warrior taking up some of the unoccupied lands, the individual was the gainer from warfare. It was in some such fashion as this that we disposed of the Indian. But now the vast body of the so-called cirilized nations lose by war. The advantage to all the rictors which once came from the impartial slanghter of the losers and possession of their lands has in this day disappeared. All the advantages they possibir 
could ohtain from war (and none of its losses) are to be had by breaking down the artificial manmade barricrs that separate countries. The sole advantage to the generality of any successful nation which may come from war is, otherwise stated, an enlarged Zollverein.

Thus, looked at, and in sober common seuse otler riews must be rejected, war hecontes wnally an utterly sordid operation, and the people who ight in it simply the cat's-paws of those nho are colder-blooded and less idealistic than the majority. We say this eren though we admit that the interesterl parties have deceived themselves as to national interests before they started to deceire others.

After all, ideals are "reated and played mom, else men would not so readily imporerish their future or surrender their lives to emrich others. The people are persualed to be for their country, right or wrong. Uneonsciously they worship a fetish. In the older time the king, so the people were told, could do no wrong. In this more modern day, when wo are for our conitry unker any and all circumstances, forgetting that, if wrong, real patriotism compels us to put it right, we are making a fetish but little clanged from the aneient form. We now declare that the people may not err. In point of fact it is possible 
the people may do wrong themselves. The chance of evil conduct is infinitely multiplied because of the docility with which they accept the teachings of those who are influenced-consciously or otherwise-in these matters by purely selfish motives. The people believe they are themselves acting, when in fact they are being played upon. Their ambition, their avarice, their chaurinistic patriotism, their pride of supremacy, are the keys. They have no more to do with the tune that is plaved than has the piano.

To all this, democratic govermment is no answer. A republic, in but little less degree than a monarchy, can be moved by artificial passion. The answer must come in a more thorough mastery of the meaning and practice of honesty internationally, which will ever penetrate behind conduct to motive.

The more profound student of economics may reproach us for not pointing out and demonstrating that "economic" interests usually mean control of the land on which all people must rork; that such control gives power orer the worker, forcing him to labor for the benetit of the holder of land titles; that therefore exploitation of foreign comntries-if not of foreign nationsmeans little else than the establishment in them of that system of land monoply which prevails 
among so-called civilized nations. In other words to him exploitation largely means an extension of that mrestricted land ownership which at home spells so much poverty and degradation and so greatly weakens democratic forms of government.

If we grant all this, however, it simply shows that at an important point national predilections influence international conduct, and that we should be the more zealons and philosophic students of national law.

To follow this thought would be beside our immediate purpose which is to deal with more strictly present international phases, leaving national law to purify itself and thereafter to purify the Law of Nations. For the moment we would make the basis of International Law at least as good as that of national law. 


\section{CHAPTER VI}

\section{SUPERFICIALITY OF TODAY'S INTERAATIONAL LAW *}

Perhaps there is some branch of legal knowledge which has received less analysis than has International Law, but it does not at the moment appear what that branch may be. The books, to all intents and purposes, fail to uncorer the differences between ordinary usages and conrentional agreements, adjective law and the basic laws by which, consciously or unconscionsly, masses of mankind embodied into States are controlled-laws which when violated bring inevitable punishment. Little attention is given to the penal and natural sanctions which follow the breaking of true or fundamental International Law. The State is treated as if it were a non-moral institution, not subject to the working's of any law higher than itself. Such a non-moral thing as a rock is constructed according to and controlled by the operations of a great variety of natural laws. Writers have been strangely blind to the fact that a State is but an aggregation of human units, just as the rock is an aggregation of molecules, and that it is not free from the laws surrounding individual and collective human existence. Wrongs which may be

\footnotetext{
*From The Advocate of Peace, January, 1922.
} 
inficted by and upon individuals are not changed into rights because the State is brought into action.

The student is perplexed and appalled by the apparent complexity of International Law-a complexity which exists largely, however, only in the minds of its professor's and not in the subject itself. He is furnished with no clew to assist lim ont of the artificial labyrintl. He is told that the sources of International Law are to be found in the writings of eminent anthors, in the practices of nations, and in conventional agreements between nations, such as are ordinarily embodied in treaties. He is not warned that much of such so-called law is but the crystallization of wrongdoing on the part of nations. It is largely left to him to discover, maided, that he has been given mere enumerations of facts, and not the results of diligent study as to the nature of law itself. He is tanght that there can be such a thing as the laws of war despite the ract that the usages of war contain none of the attributes of law.

The student, relying upon the instructions of a professor who has not been trained to use his own mind, will be encouraged to believe that a State is a creature outside and beyond law, sovereign in itself, and that, like the king, it can do no wrong. He must himself discover that this conception of a State is medieval, feudal and aristocratic- 
certainly not democratic. At the same time that he is assured States are sorereign in their foreign relations, he is told that equality exists between them-two ideas utterly irreconcilable. The sorereign knows no higher law. Equals may not, without violating equality, seek forcibly to impose their wills upon each other. If they do, then they violate law-real Intemational Law.

Thus the student has little reason to believe that there is such a thing as basic International Lawlaw which may not he disobeyer except at the cost of damage to the State itself and to hmanity at large. It is not given him to learn that there may be a comparative jurisprudence paralleling International taw. The only exception to this is the casual suggestion that the United States is a Union of States resembling in their inter relations nations at large, and from whose Constitution suggestive information may be drawn. But, if the subject is pursued, even here emphasis is laid almost exclusively upon the Union's system of federal courts. The real sonrce of the strength of the Union-the freedom of intercourse and traffic between the States-receires scant notice, and the unlawfulness (in nature) of interference with commerce between nations is ignored. The penalties for the breaking of this law in international relations remains umperceired. 
It is due to our lack of imagination that no basis is fonnd for comparative jurisprudence between the law controlling states as organized bodies of men and the law controlling individuals. Te entirely forget that, in the slow processes of the ages, we have worked out a basis of human right which may not be ignored when we consider the State at large. But mankind has discovered, as to the individual, that he may not murder or steal; that such acts are antisocial, and therefore prohibited by natural law and to be punished, directly and corporeally, by civil law. It has further been discovered that the individual possesses natural lights-rights that we know are natural, because their infringement brings, sooner or later, punishment upon the infinger, whether a person or a state. Nevertheless, no comparative jurisprudence has get taught International Law writers that theft of possessions and murder of their ownar's committed by a State, a multitude of individnals, is as antisocial an act as a like offense commitited by a single individual.

Apparently no International Law writer will recognize these and other relevant facts and appreciate the lessons to be drawn from them until the data of International Law-real International Law-have been collected and arranged and their bearings molerstood. So far this work has not 
been done either systematically or intelligently. We do not speak a true language of International Law, but a jumble of sounds which we have not resolved into their component elements.

International lawyer's as yet are without a clear test which they can apply to the facts of a new situation and determine from its probable results, as shown by experience, what may be the righteous course to pursue. If with their faulty vocabulary and store of misunderstood facts they can find no analogy, they are lost in approaching the problem. They do not know whether to test it by the gallon, bushel, wind gage, pressure gage, weather-cock, Ten Commandments, or by the principles of Machiavelli. They are worse off than a case lawyer confronting strange conditions.

The votaries of the International Law of today write grave books for the edification of the student about the events of any war which may have passed over the world, and their manner of so doing will serve to illustrate how counsel is darkened. The political facts leading up to the war receive the fullest, though often unenlightened, treatment. The interests controlling political action are lightly passed over or ignored. The more remote origins of the dispute are not traced out. The immediate events, which are results and not beginnings, are treated as the groundwork of the 
trouble culminating in war. Nothing of a fundamental character is devoloped, iniorming the reatler or students as to the rights originally violated or the rights proposed to be violated by the institution of war, for, throughout, the non-moral conception of the State influences or stifles thought.

The learned authors gravely consider whether the outbreak was preceded by a declaration of hostilities, $O \mathrm{r}^{*}$ whether the killings commenced without warning, and which would have been the proper course. They discuss the development of contraband which the war has brought about, ignoring the fact that this is equiralent to a discussion as to whether, a man's coat being taken, his vest should likewise go to the thief, and, if so, whether the watch should accompany the rest. The occasion arising, much time is spent over the law of blockade, and it is liscovered whether it has been changed or morlificd by the events of the war. The fact is overlooked that the alleged law of blockarle permits interference with the right of the neutral to trade with one of the combatants, and, justifying violations of natural right, camnot. be classed as a sound law.

The rights of neutrals are constantly described by them as increased or lessened through the actions of the combatants. No question as to the 
right of a combatant to subordinate the interests of a peaceful nation to his wishes seems to arise.

The writors discuss the use of dum-dmm or explosive bullets, gas, and other methods of human extinction, and seek to discover which is the most in accordance with Christian usage and, let us assume, the Sermon on the Mount. Ther examine the facts as to the lery of contributions upon the civil populations by the sereral armies, but any doubt as to the entire lonesty of this practice is never expressed.

As to what they regard as rules controlling the use of balloons, airplanes, bombs, and submarine mines, they call the changed practice a development of law.

In doing these several things they do not cite the conclusions of any tribunal in which the life or wellbeing of man is regarded as of any moment, or quote from any legal decisions at all, except it be the dicta of the prize courts of the parties in conflict.

They think that they are developing law when they are merely setting down a marrative of facts concening violations of the rights of untrammeled human existence, violations which are the negation of law. The reservation might be made that these facts do have the subtle relation to the 
written ol unwitten law which the acts of a criminal hare to that moral code he has violatea. As furnishing lata for raal International Law, they are exactly comparable with the criminal history of .Jack sheppard or with accomts of the exploits of others who have perished on Tyburn Hill.

The books being published, the reviewers pronounce them to be "notable contributions to the science of Intermational Iaw" -a commendation to which no criticism may be offered except that the volumes are not scientific and that they have no relation to real law.

It is not just to say that the writers of these tomes have performed utterly useless labor. There is frobably sufficient reason for the classification and recordation of eren the most unsavory events. But let us take this work for what it is, and not associate it in any way, save as a waming, with what really is International Law. The true duty of the collector of the data of International Law, mpon whose work the jurist must predicate his expositions of law, is not far different from that of the actor', whose place it is to hold, "as 'twere, the mirror up to Nature; to show Virtue her own featme. Scorn her own image, and the rery age and body of the time his form and pressure."

Bearing in mind and applying the Shakspearean surgestion, take this concrete example: In 1912 
a war broke out between Italy and Tripoli. Italian troops invaded Tripoli and finally conquered the comtry. What should be the attitude of the student of international events toward this war, and what would he find to examine and discuss? He would consider the causes of the war, inquiring particularly whether or not Italian statesmen believed Tripoli to be a land of potential wealth. He would examine, and perhaps discover, what important Italian business interests desired profit in Tripoli in the way of control of natural resources, extension of banking institutions, concessions for railways and like means of commerce, and what other business and mercantile institutions regarded it as a fruitful field for their endeavors. He would inquire curiously as to whether or not there was an interlocking political and business directorate controlling Italian politics; whether or not the interrelation was represented by the same people or by those intimately allied with them, or whether or not there existed financial obligations on the part of the politicians toward the business men. He would discover whether or not there was a jealonsy between those whom we courteously call Italian statesmen toward other countries because of the processes of subjugation in North Africa which had been carried on by England, France, and Spain. It would 
be a matter of moment to him whether or not, as against these nations, Italy was claiming her share of the loot in a field the conquest of which was resaried as relatively easy, and whether or not this conquest was claimed by Italians and regarded by politicians in other nations as Italy's compensation for her good nature while those countries were gaining control of resources in a land comparatively near to Italy. He would investigate as to whether or not an artificial desire among the people for the occupancy of Tripoli had been cultivater through artful repetitions of the fact that over two thousand years before ancient Rome har subdned it. His interest would be excited if he found that the idea had been disseminated among the Italian peasantry that Tripoli was a land of large mineral and agricultural resources, from the possession of which workers in the fields and mines of the Peninsula might hope to gain. He would want to know if minor elements had been appealed to for the purpose of influencing public sentiment in Italy, as, for instance, if the contempt which people of one religion are ready to bestow upon people of another religion had been systematically stirred up, and if an analogous racial contempt so easily brought to the surface had been excited, these not as direct causes of the war, but as stimuli to bring men to the point of 
slaughter. Catchy but elusive watehwords, created for the occasion, would not be overlooked.

Turning to the results of the war, the writer would strive to estimate the value of the "imponderables," as they are termed, such as the hatred and contempt which the war would attach to the name of Italy in the minds of Moslems, and to give full weight to the thoughts of emmity and revenge created among a subject people, thoughts destined sooner or later to find their outlet. He would measure the direct monetary loss to Italy and the burdens placed upon Italian subjects for which they could nover hope to have a return. He would try to gage the damage done by the withdrawal of men from industrial pursuits to the ways of destruction, this as affecting the direct physical loss and the necessary moral degeneration. He would not fail to examine into the effect of the war upon the commercial and political relations of Italy with other nations.

In estimating, on the other side, the benefits, if he could find any, he would inquire whether or not the war had, after all, given an enlarged field of labor for the toiling millions of Italy, and whether or not its financial benefits had inured to an exceedingly small circle of Italian financier's, while the whole burden fell upon the shoulders of those who were already sufficiently oppressed. 
This examination might well be multiplied as many times as wars have been indulged in for the past fifty years. Thus would be furnished a tremendous amount of data available to all peoples disposed to enter upon armed conflict. It is entirely safe to say that with this data gathered together new proof would be afforded that aggressive war camnot be carried on, and even what Grotius called "a just war" cannot be indulged in, without bringing terrible punishment upon the nations concerned. After all, we shall add but little to the wisdom of the poet who wrote:

When thou hearest the fool rejoicing, and he saith, "It is over and past,

And the wrong was better than right, and hate turns into love at the last,

And we strove for nothing at all, and the Gods are fallen asleep; For so good is the world a growing that the evil good shall reap;", Then loosen thy sword in the scabbard and settle the helm on thine head,

For men betrayed are mighty, and great are the wrongfully dead.

And thus it is that war breeds war, and we become involved in a vicious circle, recognized as legitimate by the International Law writers, but in which justice as between man and man, between nation and nation, plays no part. 


\section{CHAPTER VII}

\section{IMPERIALISTIC ADVENTURE UNDER}

\section{INTERNATIONAL LAW}

We have pointed out that the State is merely a multiplication of individuals. As such it is or should be, allowing only for such different sitnation as a partnership presents when contrasted with that of a single individual, controlled by the same fundamental laws, subject to the same rewards and punishments as a mere human being, and endowed with the same ambitions, desires and passions. Nevertheless, in the discovery and application of the law as applied to the single individual and to the group called a State, greatly different degrees of progress have been made. In the course of the centuries it can be truthfully said that inquiry into rights, duties and penalties for wrongdoing so far as the individual is concerned have advanced infinitely more than have inquiries as to the same matter's with regard to States.

For an indefinite number of thousands of years mankind has bloodily fought its way until it has reached a point where many fundamental legal rights have been made manifest to the stupidest so-called lawgiver because of the punishment tollowing upon their denial. We have learned that 
ail have a right to life as between themselves, though we have not adranced this knowledge to embrace the individual in his relations with the State. We know that a man is entitled to librety, that is to ay to go to and fro as he pleases; to employ himself or to be employed in any gainful way : to enjoy such amusements as he will. Incidentally we have proclaimed in our Constitutions for his benent and for the benefit of all that he may publish by print or word of mouth his ideas on "ny point whatsoever. The written law has recomized his right to acquire property, but has aleclared that he may not do so through violence or by fraudulent device condemned by law.

We have made these and other adrances, but it remains true, and we must bear in mind the fact, that eren these lessons have been imperfectly learned or are imperfectly comprehended in all their implications. To a degree the exact truth of any conchusion we may have reached is ritiated becamse of this fact. Merely by way of suggestion, as the full argument is quite aside from our purposes, it may be said that while we enjoy freedom of speech usually at any rate as to religion, we may not incluge in it in an unrestricted manner as to the confluct of the gorernment under which we live. Particularly is this true in war times when the govermment, while willing that people should 
be critical as to the ideas underlying other institutions than itself, fiercely proclaims its actions as outside of the range of ordinary discussion. So also while we rightfully recognize the existence of property, the word itself has not received its final definition, and the nature of property is at all times subject to re-examination. This we will remember was decidedly the case as late as the war between the States, and we will not forget that an infinite amount of property was destroyed without compensation (that is, not regarded as property) when the prohibition amendment was aciopted. Again our attitude toward honesty is largely conventional. If the written law tells us that a certain line of conduct in a given case is dishonest the law is usually right, and we accept it. With equal submission we regard that as honest to which the law gives its stamp of approval or at least which it does not formally reprobate. This saves the labor of thought. Nevertheless, accurate conceptions as to private honesty do multiply with the rapid increase of personal relationships.

However imperfect may be our appreciation of right and wrong as affecting individuals, and whatever changes the future may have for us, this branch of law is better understood than is International Law, which has many valuable lessons to learn from it. For this situation there are 
excellent reasons. As stated, knowledge of law on the personal side has been developing for thousands of years. When we treat, however, of growth in knowledge of law in its international phases, we must remember that its history is a short one. During the time of Roman supremacy after the rude contests of earlier years, all outside the Roman pale were barbarians, not forming real nations. Until the Middle Ages a foreigner was almost invariably regarded as an enemy. These considerations, without undertaking to develop them, forbade increase in knowledge of any true International Law among the Romans.

During the early Middle Ages the nations for the first time began to recognize themselves as entities between whom some sort of relation must exist. But it was then the courtier, the immediate servant of the king, who was the agent through whom these relations were carried on, and who led the professors, controlled by feudal teachings, to lay down with meonscious sarcasm what they called the Law of Nations. Our later developments, as has been pointed out, show the defects of the origin of this branch of what now is only pseudo science, defects which are obvious enough to all except those who are too close to it to see. International perceptions are perhaps slower in part because such relations are of necessity fewer 
and do not command the vigorous examination that acute and immediate personal interests dictate in private affair's.

If we have through fire and blood wrought out a theory of human rights as affecting the individual which, while defective, offer's nevertheless the best working basis we have, why should we not apply a like theory directly to the State? If we take this course, forgetting the prepossessions which affect us because of conditions as they are, we shall be forced to conclude that that which is dishonest in the man is dishonest in the State; that which is cruel in the individual is cruel in the State; that which is contemptible in the one is equally contemptible in the other. No bias of patriotism should blind us as to the essential nature of national acts and no blindness induced by custom should prevent our seeing the obvious.

A conclusion from all this is that there is a duty imposed upon those who would influence in the lines of justice the affairs of nations, - and this includes every individual in our land,- to demand that Uncle Sam should be, according to the best theoretical and practical standards, a gentleman and an honest man. And after all true International Law has no requirement other or greater than this. It has no mystery about it. It calls for nothing except clear and clean thinking. 
There is a copybook saying to which we give formal assent that "honesty is the best policy." If this be true with regard to individuals, slight examination will show that it is true as to mations. The tronble has been that goveruments, proud in their own conceit, limiting criticism from within, impatient of it from without, convinced of the righteousness of their actions, and lacking the cool, steady control of ideas of justice worked out and laid down within the books of International Law, have run riot over the rights of their neighbor's.

Let us apply the rule we have just suggested. If, to illustrate, that dictate of honesty which prohibits a man from forcibly seizing the goods of his neighbor had prevailed as between nations, would the victor after sucess at arms inflict upon the loser the loss of territorial power, with delivery over of moneys obtained from the subjects of the losing country, or hold the defeated nation in bondage of debt rumning over indefinite years? If, for instance, International Law had been "on the job" would it have failed to recognize that a government is a mere agency acting for other's; that the fines and penalties levied upon a government were, in point of fact, not levied upon the govermment at all but upon each individual whose purposes it was created to serve? Would 
not International Law have seen that the successful contestant was taking money from hwman beings represented by the unsuccessinl gorerrment? Would it have been able to square this conduct with the most ordinary principles of honesty? Would it not have perceived that the infiiction of a penalty upon the loser government was pro tanto reducing its subjects to a condition of slavery? For all that slavery does is to take without recompense the unwilling labor of one man for the benefit of another.

In the presence of this situation, the law writer calmly says that such is the fortune of war and such is the right of the rictor. By what right is this said? By no right except it be that superior power is recognized as right. But power and right do not spell the same thing. If it be said that a State, by the mere fact of its existence, can convert that which was wong in the individual into something commendable on its part, we may ask at what point the subtle alchemy which reverses the characacter of acts begins to operate. The prirate individual has, we shall agree, no right to kill or steal. This act is antisocial and under the ban, therefore, of a natural law, even when men are living outside the jurisdiction of formal statutes. We will agree further that no two individuals possess that right. We will perhaps agree that when a group of men is united into a village com- 
munity, they are but fortuitous collections of human beings who are not endowed with the mysterious power of transforming original wrong into right. They may not therefore rob and slay member's of a neighboring village. We will hesitate to declare, and we will not tolerate among ourselves, that a city can rightfully, becanse of its jealousy of a neighbor, destroy its inhabitants; but we suddenly discover that when several eities unite and call themselves a nation the restraints which had controlled the individual or the little group or the village or eity no longer exist. An enlargement of the members and a change of name, it would appear, have a certain moral efficacy, rather elusive it must be confessed, but very satisfying to our decires for gain and power, so that we never examine to discover if there be any weakness in our chain of argument. As practical men we accept things as they are, and with the folly so often incilent to practical statesmanship we ignore the necessary sequences of our actions.

If we turn to the results of our line of conduct, particularly as exemplified in the most modern examples, we find that it brings its own peculiar punishment, and thms its wrongful character is demonstrated. We shall show that this is especially true today. Under the old feudal conception the subject was merely the chattel of the 
lord and not an integral part of the State. The Prince by his voluntary action could transfer his subjects from his control to that of other potentates without exciting thought or resentment on the part of people who were thus treated as cattle. Of old, therefore, the penalties might have been slight and practically non-existent. Feudalism might have permitted this line of conduct with little demur. Today a democratic Law of Nations is coming into play.

Let us take a recent example from the history of our own country. In 1898 Spain, bowing to superior force, yielded her corrupt sovereignty over the Plilippine Islands to the United States. As it is argued, we quieted our consciences by paying Spain $\$ 20,000,000$. Spain was herself an interloper and a foreign power in the Philippines, even though she had exercised control there for three centuries, the Spanish people the while being punished during every year of those three hundred in that they were compelled to send armies to those islands and to expend relatively enormous sums on navies to insure their subjection and retention.

As a result of the conduct pursued by us, 5,000 American lives were lost in the Philippines, and year by year our naval expenses as well as our army bulgets have been enormously increased by 
an attempt like that of Spain to subdue and preserve our forcible acquisitions. Our exploits in the Philippines, including the strangling of a budding republic, have thus vastly increased the steady burden of taxation in the United States, and every worker, however modest his income, and every man of wealth whatever his possessions may be, finds himself compelled yearly to part with appreciable sums of money for having maintained what some call the tawdry glory of our imperialistic venture.

The evil we are told does not stop at this point. We have set an imperialistic example to Japan. Further, if we have been troubled because of tenseness of relations with that dynastic country, many say it is almost wholly because we have interjected ourselves into the affairs of islands inhabited by an alien people close to Japan and many thousand miles away from us, making our imperialism a present danger to Japan. Our punishment appears to have been direct and certain.

Some among us also argue that we are salving our consciences with the thought that we have treated the Filipinos better than some other exploiter nation may have treated the peoples of Asia or Africa which have come under its power. We have, it is true, faught Filipinos sanitation. The have given them education. We have incul- 
cated ideas among them that they did not before possess as to those principles of government which most appeal to us. All this is doubtless true. The hollowness of our excuse, it is claimed, is exposed, however, when we ask ourselves as a people whether we would have been willing to have spent on education and sanitation in the Philippines, without political control and without hope of economic gain, the money we have parted with for their possession. The answer must be promptly in the negative. The development of the Philippines in the fashion which we use as an excuse, we are told, renders our future punishment all the more assured, for that every Filipino whom we train according to our ideas must ask himself why our practices in the Philippines in matters of govermment have not accorded with the principles we maintain as ralid at home. Thus he grows to be a more and more intelligent and dangerous opponent of American rule. In the end it is claimed as manifest to all who will not shut their eyes that the Philippines will gain their independence from us with no thanks returned to America.

If our exploit in imperialism in violation of fundamental International Law, and involving, as said, a strong-arm taking of political power for economic benefits, should seem too painful a subject to pursue, let us ask ourselves the net gain to 
Germany in the long run through the taking of Alsace-Lorraine. Assuredly this was one of the elements which made, some time or other, another. Franco-German war a practical certainty. It gare an impetus to Germany's course of military derelopment and consequent imperialistic adventure which would have been largely lacking if these lands had not been taken.

If we need other evidence that violations of natural right indulged in by nations carry witl them an appropriate punishment and therefore stand condemned in the form of real International Law, whatever professor's may say, or fail to see, let us turn to India. We find that this country. vast in population, was first seized by England for the benefit of a trading corporation; and that gradually the workings of the corporation were taken over by the English government. It is believed that for two centuries it has been exploited as we say in common parlance for the benefit of England. In fact this belief has but the semblance of truth. India has been held for the benefit of the English army; for the benefit of that small section of English society which has furnished its (civil servants; for" a little circle of commercial exploiters, and to the detriment of the average man of England. For what has this adventure prorluced? Its retention has made necessary an 
enormous navy and an increased army. Gibralter, which has no proper relation to England, has been taken to keep the naval route clearer. The same reason has justified the holding of Malta, with no natural geographical or other relation to England.

Again, England, by doubtful methods, took hold of Egypt, and made a subject nation of millions of people who know England only to hate her. Aden was added to the list to help complete the line of protection. The impoverished and suffering millions of the English Islands, many of them stunted in their physical growth and mental development, attest the failure of the English in this imperial enterprise. It is true as ever that- "Hell is a city much like London."

We may say all this with genuine admiration for the superior progress in establishing and rendering secure their rights, England's subjects have made during the centuries. To England we owe much of the political and social advances we enjoy and which we fondly believe superior to those enjoyed by the citizens of other nations. She herself has failed to carry into international relations those ideas of right action which she has been compelled to recognize as paramount between man and man at home, and the handwriting on the wall grows more and more distinct. 
It is a dreary, sordid history we have to review when we consider the degrading growth and corrupting decay of govermments which have indulged in foreign conquest-a listory from which men have so far learned little and Intermational Law as taught has learned nothing. Take the instances which naturally spring first to one's mind. We have Spain with its wonderful colonies, and Portugal in a like situation, each after infinite expenditure of men and money flattering itself with the story of its greatness only to sink reduced to a low scale of relative standing among the nations of the world. England in a more modern way follows their example. We have the United States feebly tracing the same course, tormented by conscience and suffering materially. All these things have been done in the name of the glory of the kingdon, or empire, or we might claim for the United States that of the American people. Fach instance has brought mearned and undeserved wealth to a select few. Each instance has spelt, poverty and moral degradation to the immense mass. Such violations of real International leaw, if one's taste be not too particular, may seem commendable in antocratic government. They have nothing in common with democracy, the duty of which is to secure the wellbeing of the common man above all things else. 
The miversal results of these attempts to subject alien and foreign nations to the rule of the conqueror, with the consequent injury and ruin of nations taking this course, points to the existence of a natural Law of Nations infinitely more sacred than the words of the printed page.

We will be told that this may be true, but it is all too idealistic for a practical world. But practical men, ready to take momentary advantages of opportunities for material gain, have brought enough destruction upon the world. Idealism should have its day. Meanwhile we will not forget that millions of men have offered up their lives for false ideals. Our duty to discover the true ones in international affairs is imperative. 


\section{CHAPTER VIII}

DEFICIENCIES OF INTERNATIONAL COURTS UNDER PRESENT CONDITIONS

"Justice, Sir," said Daniel Webster, "is the great interest of men on earth.", There is little doubt that in making this statement Webster phrased an universal aspiration. Because of this concern of mankind, it is easy to understand that in seeking to build such a world state as would insure justice and consequent peace men should have turned to the idea of courts. The unfortunate fact is that in so doing mechanism has been emphasized rather than principle. Instead of inquiring diligently into the elements of justice, however administered, the machinery which we use to obtain justice has seemed superior to the spirit which must guide the machinery. We have acted as though we thought that if we once possessed the tools justice would be ground out automatically, without further effort on our part. Laboriously we have been placing the eart before the horse. The point of the argument has been missed. Te might as well regard China as a land of justice becanse it possesses courts and judges. We would overlook the fact that in China a judge will, with the same vocal inflection, direct a man's head to be removed whether he steals ten pieces of "cash", 
or murder's his wife. The principles of evenhanded and compensatory justice are unknown, although the courts function with certainty and expedition. We must awake to the fact that there is no magic in the name of court.

The conception remains prevalent, however, that if we but establish a body which we may call a court, differences between nations will be settled and war will cease automatically, or at least through the effinx of time and by the growth among nations of the habit of resorting to judicial processes. It is forgotten that the judicial hanging of sheep stealers and highway robbers in England, persisted in over hundreds of years, did not make life more secure or appreciably affect the census of thieves. Better conditions prevailing in England and in this country were accomplished by the rise in the standards of comfort, education and morality which was going on entirely outside of courts during all the time that the gibbet and chains were familiar spectacles. This rise has gradually educated the courts themselves into clearer ideas of that justice with which they were originally unfamiliar even superficially. For these reasons we should stress the study of justice rather than that of forms of administration, whether classified, under present nomenclature, as legislative, executive, or judicial. 
In our search we will not forget that peace, which it is thought will be biought about through the establishment of courts, is not a thing to be sought lor as a tangible good, but will be the senumee of knowledge and practice of justice, compled with a gradual suppression of interested ambitions, unenlightened selfishness and national lawlessness.

The courts at best have but limited usefulness. They interpret or arminister what is reputed to be law or what, under all the circumstances of the care, bearing in mind existing acceptations of law, may be regarded as proper. While we speak of them as courts of justice, they are but imperfectly so eren in private affairs. Up to the present time it las never been proposed in any authoritative way to establish international courts of justice approxinating in their workings even to the imperfect advancement attaching to those for the settlement of disputes of indiriduals.

We will not subject ourselves to any illusions with regard to courts. They are not better than the intellectual and moral surroundings of jurges would require. They make no imovations. They blaze no trails. They are essentially and necessarily reactionary. In such advanees as they make, from the nature of things they are often behimi the bus thonght of the community. Their er- 
rors and their slowness of advance are continually corrected even in this country by statutes more directly expressing public progress or by Constitutional amendment." This is not to attack them or to minimize their usefulness, but simply to state the facts of the situation. If we consider, therefore, our experience within the nation, we have no right to expect large growth in our knowledge and application of justice to come throngh the existence of courts.

At the most an international court as now contemplated, and we shall refer to the subject later, will be a court of law and not of justice (whatever name be given it), two things confusedly merged into one in the public mind. Even as to the national courts there is a certain truth in the remark of a well-known judge that the purpose of courts is not to administer justice but to settle disputes. To illustrate the difference between the administration of law and the administration of justice by a national court we will take the ease of a fugitive negro slave before the war who had been found in a Northern State. Courts of law, being then as now controlled by statute, would direct a return of the fugitive to the master. This

\footnotetext{
* E. G.: As to statutes, Federal Employers' Acts, revising " Fellowservant" and "assumption of risk", doctrines of courts, and as to Constitutional amendmnets, the "Income Tax amendment," reversing the ruling of the United States Supreme Court.
} 
was done even when the whole community abhorred the action taken and the judge himself felt that he was inflicting injustice. Many a time has it occurred in other cases that the judge has detested the thing he was called upon to do, but as a servant of the State he has followed the course its corles have laid down for him. We need not follow this line of discussion further. It perhaps suffciently appears already that law and justice are not synonymous and that even in national affairs we have much to do to make their lines coincident. Internationally we can scarcely be said to have commenced this work.

In discussing intermational courts there are two great questions about which we should make ourselves entirely clear, as, lacking clarity of vision with regard to them, we are likely to meet with severe disappointments. The first of these questions is, what shall be the basic principles which must control the operations of an international court? The second is, what shall be the limitations or the extent of jurisdiction of such a court?

Let us address ourselves to the first of these questions and determine if we may whether, in the cxisting state of what is called International Law, we may expect from an international court results commensurate with its assumed importance. If we find as the result of our studies that the princi- 
ples which as matters now stand are to control the operations of the court are in themselves outworn, medieval, corrupt and false, and that the court in its findings is to be guided by them, we must conclude that the workings of the court will produce a so-called justice which is warped, twisted, and rotten. There is no secret process by which dross passing through the furnace of a courtroom will be converted into gold.

Without taking the time at this point to elaborate the argument, we many enumerate a few of the many vicious propositions which today would be accepted by a court. Among them are:

A state is a non-moral creation, only to be held responsible to others for its actions by its own consent.

A state possesses such a right of sovereignty as enables it by force if it can to impose its will on other states without being judicially accused of wrong for so doing.

A state must judge for itself what affects its own honor, vital interests or independence.

A state, after a successful war, has a right to impose its will upon the vanquished.

A state, provided it has sufficient power, may possess interests within the jurisdiction of another state and dictate the management of its affairs. 
A state may acquire from an alien conqueror complote jurisdiction over a vanquished people, violence creating title.

If we commence, as muder present rules we must, with the accentance of the propriety of such a chatic condition of law as wo have just indicated, what right have we to expect that any court, with its conservatism and love of precelent, can bring about changes beneficial to mankind? The changes must cone from some other somee, and, being made, it will be the duty of the courts to give them suitable application. We are building our proposed judicial system upon a shifting bed of sand.

But if we had basic law such as self-respecting and really intelligent courts might administer under all circumstances, then, second, what about the juristiction we propose to give our international judicial bodies?

National courts as at present constituted possess infinite powers which we shall find refused to intermational courts. The national court has power to say "Thou shalt not" as well as "Thou shalt.' While no eriterion as to their relative importance, it is interesting to note that among the Ton Commandments given the Children of Istael there are eight which in effect say "Thon shalt not," and there are but two which in truth are aflirmative conmands. 
The ordinary court of law will enter a judgment fixing the liability of the defendant and commanding payment in a civil case or prescribing condemnation in a criminal one. Up to this present all that international courts of arbitration, as they are called, have ordinarily accomplished has been to command the parment of money for damages inflicted or losses incurred. It is true that in some instances these courts have been authorized to lay down rules of future conduct. In so doing they have not acted in a judicial capacity but in a legislative one, and to this extent have not been true courts.

Let us revert to the further powers of our national courts. They may say, as international courts may not up to the present, "Thou shalt not." They stand in the way of trespass upon property and in certain instances of trespass upon life. They have a general power to re-place the parties in litigation in the positions they occupied before offenses were committed. Their jurisdiction may also be what one may call anticipatory. Commission of wrong being feared, the strong arm of the court is invoked to prevent it. The very existence of these powers has in innumerable instances so influenced the minds and conduct of men as to make resort to them unnecessary. These 
thing's may not be done intermationally lest we offend the mystical sovereignty of the State.

In addition to the ordinary remedies to which we are accustomed among ourselves there may exist the writ of quo uaranto through which the court inquires as to why particular offices are taken or held without right. There is further in the common-law practice the writ of mandamus, by virtue of which the court directs ordinarily not the payment of money but the doing of things which have been left undone and which in law should be done. There are of course further legal remedies, but these will suffice for the purpose of illustrations. Upon these fields no international conference has yet had sufficient temerity to venture.

If it be thought that some error is made in these views with regard to the narrowness of the jurisdiction of international courts, let us consider a proposed field of action as recently worked out by eminent jurists who recommended their scheme to the League of Nations. And such comment as we shall make will not be directed to the defects of their work. We point out that with abundant foundation to be discovered in the soealled law of Nations of today, such work is of comparatively slight value because the foundations are in themselves rotten. 
In approaching the subject the jurists in question had in mind the creation of what they esteemed to be a court of justice rather than a court of arbitration. The distinguishing difference between the two is that a court of arbitration carries with it the implication of adjustment and settlement, the bringing together of nations on an agreeable sort of basis not necessarily that of exact law, while on the other hand a court of justice is presumed to act in strict compliance with. the universally established ideas of law. The sources of International Law suggested to control the judgment of the new court were:

"(1) International conventions, whether general or particular, establishing rules expressly recognized by the contesting states;

"(2) International custom, as evidence of a general practice, which is accepted as law; nations;

" (3) The general principles of law recognized by civilized

"(4) Judicial decisions and the teachings of the most highly qualified publicists of the various nations, as subsidiary means for the determination of rules of law." **

Such law, however, was only to be invoked, save with the consent of two opposing parties, where the court was called upon to-

"Hear and determine cases of a legal nature concerning:

"(a) The interpretation of a treaty;

"(b) Any question of international law;

"(c) The existence of any fact which, if established, would constitute a breach of an international obligation;

* The Project of a Permanent Court of International Justice, by Dr. James B. Scott. 
“(d) The nature or extent of reparation to be made for the breach of an international obligation;

“( (e) The interpretation of a sentence passed by the court.",

While other matters might as indicated be referred to the court, there way nothing obligatory, molally or otherwise, on any nation to make such reference. If a dispute did not involve the matters above mentioned the court berame powerless.

In an anticipatory way, preventing in arlvance the rising of difficulties, the court was allowed to sugerest provisional measures to preserve the respective rights of either party, but these measures it is clear from the whole docment could only be suggested in cases where the court might have ultimate jurisdiction, its limitations being as stated above. The sum and substance of it is that only in what is termed a "justiciable matter" should the conrt act, and that otherwise the mations were to be free to submit matters upon which they were in discord. The enrious thing is that the things which were left outsicle the court's powers were the very things about which nations fight, and those as to which juriscliction was to be given were those which do not ordinarily excite the passions of men. This will seem true when we remark that nations are not griven to going to wal nver questions of the interpetation of treaties, abstract propositions of lnternational Law, the existence of facts constituting breach of international obliga- 
tims (ordinarily collection of debt due founded upon postal treaties or application of a customs regulation and the like) or the nature and extent of reparation for non-payment of a debt. They go to war because of interference with what they assume to be their vital interests or, in cases now growing rarer, of infringement upon what they are pleased to term their honor. These questions are not regarded as justiciable, and therefore may only be made the subjects of examination by courts when all parties agree.

With all their weaknesses the propositions of the jurists were too advanced for ahoption literally by the League of Nations.

It will be instructive to examine through an illustration the difference under these rules between the attitude of national and international courts. The young law student is told early in his career of the complainant seeking relief from the chancellor saying that he and the defendant had engaged in business together on Hounslow Heath; that in the conduct of their affairs they had accmmlated certain watches, purses and other articles of value; that these were in the possession of the defemlant who had refused an accounting, for which prayer was made to the court. If memory serves, the complainant and his lawyer were both sent to jail for contempt, and taught that no accounting between 
thicres would be granted by a court of justice, and that it was necessary always for the complainant to come into court witlir clean hands.

Assume that nations $A$ and $B$ agree that for the benefit of their respective nationals they will, by the use of navies and judicious suggestion of the use of armies, and other forms of compulsion or corruption not in private life considered legitimate, obtain from nation $\mathrm{C}$ (the selection of the initial is purely fortuitous and need not be considered as indicative of any particular country) business and commercial concessions of great prospective value. Assume success in the undertaking. Assume that afterward a dispute should arise between nations $\mathrm{A}$ and $\mathrm{B}$ as to the division of profits under the agreement through which these benefits were obtained. The world court, as it exists, would interpret the agreement and divide the profits, and then stop. International Law would not have recognized anything inherenty wrong in the conduct of nations $A$ and $B$, and the courts would recognize their limitations against trenching upon the "vital interests" or "honor" of the disputants.

Let us therefore examine and discover if we may what these things are which are so incapable of julicial determination that even courts may not ordinarily examine them. 
First and foremost we meet the question of the vital interests of the State. This is not capable of exact definition. They are what a State says they are in any particular instance. They vary with the size of the State. Those which are not vital to Switzerland, it being a small country and incapable of enforcing its will upon others, may become vital in the opinion of the statesmen of Japan when she knows that by force of arms she may be able to compel other governments to accept her view. In other words, the connection between might and vital interests is a close one. The weak nation possesses no vital interest which may be maintained as against the strong nation. The theory of our national courts that they enable the poor man to prevent aggression on the part of the rich finds no place in this proposed international jurisdiction. When, therefore, in this regard we entertain the idea that an international court will be a protection, we find ourselves aided by nothing more substantial than the baseless fabric of a vision born from the use of the word "court."

But more specifically what are the vital interests of a State? We are right if we say that they refer to little else than policies of aggression, historic perhaps, that the state desires to pursue as against other countries, or policies which find their roots in a fear of damage to be inflicted from the outside. 
Important, too, in creating these vital interests are the influences of the economically ruling classes in a country. If they have determined upon the selfish exploitation of particular countries controlled or occupied by weaker nations. they are often able to influence their gorermments to protect their capital invested or to be invested, and the selfish interests of the exploiters by a jugglery of language become the vital interests of the State. Tyranny, fear, and avarice are therefore the originator's of practically every "vital interest" which may be named. Again we repeat, these are the very things which courts are ordinarily given juriscliction to check in our national field of action. The formation of courts, therefore, which are forbiclden their consideration appear's to confirm the sanctity of vital interests.

Underlying all of these phases of vital interests is the fact that the State fears injustice from others or intends to preserve its own power of committing injustices. If all nations were to pool, as it were, their "vital interests," and submit themselves without reserve, under proper conditions of International Law, to impartial courts, it would speedily be discovered that so far as the immense mass of their citizenship was concerned more had been gained by the apparent sacrifice than had been lost. We are brought again to the 
conclusion that except by resolute acceptance of right dealing as between nations all the paraphernalia of courts so far proposed will lead to nothing and that this study is one to be pursued in the first instance far ontside the courtroom.

We have as a next reservation that of honor. Internationally this offers' a curious study. It is not dishonorable among nations for a State to kill the inhabitants of another State, poscess itself of their govermment and its property, subject their inhabitants to the slavery of debt, take away such private property as may seem desirable, use the lands of another State when convenient as the base of attack upon a third State, indulge in any petty meanness in its custom-houses or its waterways or railways; hamper the development of other countries to the advantage of a few of its own citizens, or commit an enormous number of other offenses bom of selfishness $0 r^{\circ}$ greed. All of these acts in the eyes of the nation committing them are permissible or even praiseworthy, and do not indicate a defective sense of morality or retarded intellectual development or ontraged decency. They are all honorable, and carry with them no condemnation judged by the standards of existing International Law or practice.

The failure on the part of another nation to salute a flag or the breaking of the shield of a Con- 
sulate by a crowd of ragamuffins may be an infraction of honor and lead to war. It is noteworthy, however, that this will never take place unless the nation whose honor is infracted is much stronger than that the citizens of which have committed the offense. If the nation furnishing the offense, in addition to being weaker, possesses commercial possibilities, the control of which would add to the wealth of the more influential classes in the larger one, the infringement upon honor becomes more serious and less capable of adjustment, and impossible of reference to arbitration. Inaccessibility on the part of the offender will also affect the requirements of honor. A supposed insult to the United States committed by the Swiss will be readily condoned. One committed by Mexican citizens becomes very acnte. The weakness, accessibility, and potential wealth of Mexico somehow magnify the insult.

"Independence" must not be arbitrated or be subjected to the rude decisions of courts. Independence within the range of the proper activities of the State-that is, internal-we may well understand, and with this independence no court would undertake to interfere. But what is meant is independence in the actions of the State with relation to other powers. This is absurd today and nom-ristent. The only way to preserve independ- 
ence is to shut tight the doors of the nation as was done by Japan before the advent of Commodore Perry, or to be an ontlaw nation. When a nation enters the family of nations and claims the benefits of its new position, it is no longer independent, but, whether it so wishes or not, finds that all nations in its position are interdependent and controlled by the written and unwritten laws of their environment.

The reservation of independence simply means that the State shall itself be the judge of how much of its control over its own external actions it parts with by entering the family of nations. Social order can be based upon no such proposition. We either keep out of the game entirely or the laws of society determine what their exactions against us shall be. We must be either a hermit or an anarchist whose hand is against all government. We cannot be social and unsocial in the same breath. 


\section{CHAPTER IX}

SHOELD ANS INTERNATIONAL DISPUTE BE

PESEHIED FROMI ARBITRATION?

A man presents himself at the portals of Ellis Istand. Our laws, the justice or effieacy of which we do not discuss, require us to question him. "Do you believe in ormized govermment?" $\mathrm{He}$ answers, "I believe in govermment, of course, but let it not interfere with ne. I aceept it so long as it does not affect my personal independence, so long as it leaves me master of whatever concerns mine honor and permits me to arenge myself upon all who infringe mpon that honor. I believe in government so long as it allows me, an sovereign over my own destiny, to determine for myself what interests are vital to me and to slay those who in my oninion trench mon them." To the man who so replies, we say: "Your recognition of government is formal; your appreciation of right as between man and man is moleveloped. If admitted to our comtry, you would he a danger to our wellbeing. In very essence you are an anarehist and as such may not enter."

* This chapter was delivered as an address before the Pennsylvania Peace Congress May 19, 1908. Subsequent reflection has shown deficiencies in international courts nnder present conditions leventing them from having large value. See Chapter VIrT. 
Let us suppose a new State las arisen demanding recognition and admission to the family of nations. Its representatives, when entering into treaty obligations with other nations, are permitted to withdraw from submission to the judgment of any tribunal formed to adjudicate international difficulties, all questions which affect its independence, its honor or its rital interests. Whether in fact a dispute involves any of these elements, it retains, and is recognized as having a right to retain, the privilege of determining for itself. At most today we ask, not insist, that it shall arbitrate pecuniary claims.

When such a position is taken in International Law, is not anachy grown large logitimatizer? Little harm can the sentiments of one man do. His opinions and interests will be corrected and controlled by the opinions and interests of his neighbors. Perforce he must submit to the judgment of his fellows all the questions as to which theoretically he claims the right of self-determination. But when a million men, calling themselves a State-which, after all, is but a collection of human units-determine without restraint its justification for war over suclı questions and even settle for their rery existence, thus claiming the right, governed only by their own sense of justice, to steal from and to mmder another mil- 
lion of hmman units who exercise a similar power, we have chaos unspeakable-chaos legitimatized. By International Law, paradoxically speaking, thus we have regulated chaos. And yet analysis show that after all there is presented to ns but the simple problem with which we opened,-the right of anarchy,-a problem confused only by the indefinite multiplication of the participants.

And we will not lose sight of the fact that even as to pecuniary claims, in almost every case a nation may refuse arbitration, upon the pretense that the very advancement of such claims is a reflection upon its honor, perhaps because there is offered a suggestion deemed disgraceful to its administrative or judicial officers, to which suggestion it refuses to submit. Must we not, then, conchude that our International Law is but taking its first few feeble steps; that we are just entering upon a long and painful period of education, the end of which will be to assinilate international justice to national justice?

Taking a look into the futme, we may recognize that the time must come when such a thing as Intermational Law relating to warfare will be as obsolete as is today common and statute law relating to the status of slaves. I remember as a boy reading a book, then old, laying down the rules of the Code Duello. Today such a work prescribing the 
amenities of private murder would seem as out of place in our cirilization as, let us hope, in the future will seem the half of the volumes of International Law which are now given over to the examination of the courtesies of public slaughter.

But our course seems clear. We must develop the idea of arbitration, insist that no question is too small, no interest too great, to be subjected to the judgment of disinterested and competent men, for, internationally as well as in our private lives, something on its face immaterial may lead to consequences coloring history. Tracing the causes of wars to their obscure beginnings, how often we find that foolish jealousies, accidental or intentional lack of observance of the smaller courtesies of life, have lead on and on to the slaughter of thousands. But if apparently small things can with justice and advantage be settled between man and man and nation and nation by submission to impartial men, with how much more obvious reason should the larger and more dangerous matters take the same course! And, after all, can those who take part in them best determine whether the matters in dispute be large or small, be great enough to justify the killing of thousands, or insignificant enough to be atoned for by the payment of a few dollars? 
How needless does calm investigation show to have been even modern wars conducted by men priding themselves upon their civilization? Can any one living tell beyond a peradventure what was the Schleswig-Holstein question, which involved a. bloody conflict. Was there just and sufficient cause for the Franco-Prussian struggle? Does any one attach large importince to the supposed questions leading to the Crimean War, and was the Charge of the Light Brigade, immortalized in poetry, sufficient return to the world for thousands of deaths among the subjects of four nations?

When we look back at all these struggles, standing in the disinterested attitude of strangers to them, living as short a time as from thirty to fifty years after, and consider their doubtful or inadequate causes, can we not agree that the arbitrament of a stoup of cool and disinterested men living contemporaneously could, if asked, have afforded a peaceful and honorable solution? And if in any of these cases the causes were so slight or so involved and so difficult of reasonable statement as to preclude reference to arbitration, may we not think such fact to be sufficient to condemn those cregaging in these wars as more brawlers in the family of nations?

Visible advances toward the goal I have indicated have been made, and in the making 
America has taken an honorable and leading part. Repeatedly have we arbitrated boundary questions, questions of a nature which, in a less cirilized age or with less adranced participants, would have led to frightiul wars and have been regarded by the countries in dispute as affecting their honor and vital interests. Very many commissions to which we have been parties have settled claims disputes touching wrongs to individual citizens of a character which, under less happy cilcumstances, would have spelt war, and for even smaller aggravation than has been involved in them less favored nations have with heartiness entered upon throat-cutting and destruction. Can we not even today take pride in the Alabama Claims Commission, which satisfactorily solved questions which might be classified as of honor and rital interests, although ostensibly determining only pecuniary liability, and which made this settlement at a cost which, compared with that of a week of war, was infinitesimal?

Even in the small matter of claims of individual citizens no nation can properly be a judge in its own cause. Many a time has this been illustrated, and I will refer but briefly to its latest demonstration with regard to Venezuela. When the ten commissions sat in Caracas, in 1903, to determine the claims of as many nations against Venezuela, 
there were presented before them demands aggregating in round numbers $\$ 36,000,000$. The commissions and umpires determined that but $\$ 6,500,000$ should be paid, or, roughly, eighteen per cent. of the original amount of the demands. One nation, as a condition precedent to the execution of the protocol of arbitration of her remaining claims, demanded payment in full in advance of certain claims aggregating nearly $\$ 350,000$. For precisely similar claims submitted to arbitration she received twenty-eight per cent. of her demands, indicating fallibility, as I believe, when she acted as her own judge, and demonstrating that the advance parment was largely moustifiable. The experience of other nations before like tribunals was of the same general nature. And the history of claims arbitrations furnishes many similar instances.

But what is honor, about which nations hesitate to arbitrate? For theft, for murder, we have a definite measure, born of the miversal conscience, the same yesterday, today and forever; but honor, as the ter'm is applied, is a mental concept varying with the mood of the times. He who accuses my honor loes not rob me. Honor is only to be lost by my personal act. The impeachment of my honor may call for self-examination to determine whether the accusation be well founded. The 
death of the offender does not adjudicate the falsehood of the accusation.

But if the delivery of an insult be considered to be an impeachment of honor, should the reply come in the shape of war? If a man or a nation be insulted, as we ter mit, is the insult extinguished by the death of the insulter? Does not his killing convict us rather of want of discretion and temper? Is not the best answer a well-ordered life and established good reputation? Should not other resort be forbidden to us than declination of further relations with the offender, who, individual or nation, has merely sinned against good manners?

A reservation of independence as not the subject of arbitration seems, on analysis, meaningless though harmless. Arbitration postulates an agreement between equals. Questioning the independence of one party or the other involves a doubt as to their equality and is foreign to the idea of arbitration.

When we treat of vital interests we touch a subject never properly to be withdrawn from arbitration. What are vital interests? They are today whatever the nation declares to be such and withdraws from arbitration. The so-called vital interests are matters of commerce, trade and politics. As to matters of trade and commerce, we shall sub- 
mit that their advancement as a basis for vital interests is founded upon a misconception of the purposes; of government. As I take it, governments are formed to preserve the true liberty of the individual, to protect him in his rights of person and, as subordinate to his rights of person, his rights of property. They are not formed to extend and develop commerce and trade as such. Properly speaking, no nation has political interests beyond its own borders, and were we to enter upon the reign of arbitration, no question of political interest, as we shall attempt to demonstrate, conld properly arise.

Politically speaking, vital interests are, when analyzed, found to be based upon either a desire to ultimately possess something now belonging to another or a fear that a strong nation may violently so enlarge itself as to endanger us. With the thorough establishment of umestricted arbitration we will not be able to indulge our predatory instincts at the expense of our neighbors. With such condition we will not fear lest another nation so agrrandize itself by violence as to be a source of danger to us. At one and the same time we would restrain our own unjust acquisitiveness and we would lose our fear. The thorough establishment, therefore, of arbitration means the cancella- 
tion of the term "vital interests" as applied to politics.

Can we hope for justice from arbitration? We might, in view of the course of our discussion, respond by asking, Has justice been obtained from war? Long ago legislators found that the wager of battle failed to secure justice as between man and man. Without lengthening the discussion, we may believe that armed conflict has not on the whole advancer the rule of right. While at one time war has served to check inordinate ambition, at as many others it has furthered its purposes. We may concede that in private matters justice has often gone forward with halting steps, has even at times scemed to go backward; yet who among us would dispense with the conclusions of judge and jury and revive the wager of battle?

From the beginning, with the adrantage of national precedents and experiences, we may expect arbitration to bring us approximate justice. That always exact justice should be rendered may not be expected. The members of our Supreme Court, differing as they frequently do most vitally, will not say that this tribunal has never erred. But, despite the possibility of error, we find that order and the welfare of the community must be maintained even at the chance of individual injustice, a chance which no human skill can eliminate. 
But arbitral history leads us to the conclusion that more than an approximation of right may be expected, that a tribunal which is the eenter of observation by the whole world will seek to give, and will give, a judgment as nearly righteous as may be. In the whole history of arbitrations but one has ever been suspected of corruption, and, by joint agreement, its findings were reviewed. Slight criticism may be made of the generality of other like tribunals. Today, doubtless, even the English will agree that the findings of the Alabama Joint High Commission were just.

Let it not be said that the ideas to which I have sought to give expression are too advanced, are impractical. It is only by "hitching our wagon to a star" that we may progress. Let us not forget that there is nothing blinder and stupider, nothing less practical, than the so-called practical man; that only among the dreamers of dreams of human advancement are to be found those whom the flow of events demonstrates to have had the clearness of vision of the truly practical man. 


\section{CHAPTER X}

SOME SUPPOSED JUST CAUSES OF WAR *

Diplomatists and statesmen-we must mention both, for all diplomatists are not statesmen, and all statesmen are not diplomatists-agree often and so express themselves in treaties, that for honor and vital interests nations may wage what is dignified by the title of "solemn war," and that they must be permitted so to do at their good pleasure, even though the doors of the Hague tribunal of arbitration swing freely upon their hinges, and possible judges wait the sound of the footsteps of the representatives of litigant states. Honor and vital interests-how sonorous these words sound! Resolve them into their elements-passion, avarice, commercial and territorial aggrandizement-and the result is verbiage so crude as to grate upon modern susceptibilities. Let us not continue to use grand words to conceal ignoble thoughts!

But it is only those aggregations of human units that we call nations that may, without crime and without judicial punishment, slay, burn, rob, and destroy. Why this logically should be the case we

* Address at the New England Peace Congress, Hartford, Conn., May 9, 1910. 
are at a loss to understand. Why the inherent rights of the individual to determine such questions as concern his honor or vital interests should be mercilessly abridged, and why cities and tows (and not nations) should be deprived of the fuls and free exercise of their most violent passions, one is unable to comprehend. Should not the power of both city and nation, or else of neither, be submitted to the ruling ane of the judiciary? Is there anything peculiar about the situation of a city or of a State which should deprive it of the free cxercise of its faculties? Let us examine into the question by considering first a couple of supposititions cases, either of which may find its full parallel in history, and offering a justification for war fully as well founded as the justification furnished for many wars of the past between nations.

New York, as we all know, is a great collection of human beings, greater than was boasted by all the cities of Greece, of whose wars we read with sanguinary pleasure,-greater than Rome possessed after she had subrlued all Italy. New Yorker's are overflowing her civic boundaries into New Jersey, even as Japanese are overflowing from Japam into Korea or Manchuria. Let us listen to the musings of a future chicftain of Tammany Hall, whose domain is coextensive with that of Greater New York. He says: 
New York is imperia, and every New Yorker feels the glow of patriotic pride when he gazes on the rast fleets coming from all quarters of the globe to share in the profits of her commerce. The bosom of every home-loving New Yorker must swell with pride as he contemplates her magnificent structures, at once index and emblem of her greatness. Here liberty reigns, here the son of the poorest immigrant, as illustrated in my own person, may become ruler. But with all this, New York is in her swaddling clothes. Imaginary lines bound her on the north, while to the west the jurisdiction of the eity is limited by the North River, beyond which a New Yorker may not go without being in danger of losing his political allegiance and being absorbed by an alien community. Every patriotic instinet demands that New York should extend her boundaries so that her sons may have room in which to live and contribute to the glory of their native eity.

And withal a subconscious voice whispers, "I et this come to pass, and greater will be Tammrary and more luscious the spoils thereof."

What more effective appeal to true patriotisn conid be made! And when you add the promise to the valiant sons of the Bowery or of Harlem that the rich lands of the Jerseys shall be theirs, that the superabundance of their neighbors in cows and corn and strawberries shall be their abundance, can you not imagine with what fervor the embattled warriors of Yorkville and the Bronx, the Bowery and the Battery, would fall upon their weaker neighbors across the North River and openly put to the sword each offending owner of a herd of cows or of a promising strawberry patch? Axd the cause of war, that is, the ostensible cause of war? No matter. Perhaps a bibulous 
New Yorker, suffering from the Sunday drought of his eity and seeking consolation in Hoboken, has been arrested somewhat roughly and given a disagreeable sample of Jersey justice, against which every city-loving eitizen of Manhattan raises protest and cries for war. Anything will do as long as the desire exists for dominion over rich lands across the river, as long, in other words, as the "vital interests" of New York's rulers-money always being vital-demand an extension of New York's power. And now that we have the honor of New York assailed in the person of her intoxicated citizen, vital interests compel war.

Yet we live in such an unmanly, effete, and degenerate age and country that should the mighty cohorts of Tammany, desisting from the milder pleasures of Coney Island, advance upon New Jersey, the United States, whose peace had been disturbed, would speedily put them to rout.

But withal, reason would rest with the Tammany chieftain. His orator's could, with propriety, contend that the entity he represents was old enough, big enough, rich enough, to be allowed to fight without foreign interference. With patriotic pride could they point to examples of cities less importint whose struggles, based upon identical minciples, occupy many interesting and laudatory pages of history. With swelling pride could 
they repel the idea that Californians and Kentuckians and Vermonters, having no knowledge of, or sympathy with, their patriotic aspirations, should band themselves together to subdue the manly New Yorker, struggling only to advance his peculiar civilization.

Their logic, from the standpoint of the Englishman subduing the Boers, the Japanese seizing Manchuria, yes, the American pursuing the Filipino or forcing him to take false oaths of allegiance, would be irresistible. But logic does not always rule, and the New Yorker would find that, save by the permission of the Jerseyites, and with the leave of yokel representatives gathered in Congress from all parts of the Union, and the consent of the New York legislature, the rule of Tammany must remain confined to such parts of the State of New York as the State shall permit.

But let us approach the problem from another point of view. Great as is New York, let us imagine that Boston rivals her in the commerce of the world; that every favoring breeze brings to Boston the largess of the whole globe; that, despite all the Gotham efforts, Boston's growing commercial advantages directly affect New York, whose rent rolls steadily diminish. Imagine there arises a newspaper Cato, whose morning and evening editions print at their top, in blood-red 
letter's, Delenda est Boston. The public mind becomes attuned to the cry. In an unlucky moment a Bostonian in New York, whose unhappy pronunciation of the letter "A" reveals his origin, becomes involved in difficulties necessitating a visit to the Tombs. Boston peremptorily dermonds his release. New York scomfully refuses, and New Yorkers are insulted by Boston's wrathful rejoinder. Here again honor and vital interests demand blood, and under the old logical rule the solemn arbitrament of war must determine the issue. Alas! once more the men of other places, heedless of the honor of the two cities and blin! to all interests save their own, step forward and forbid resort to any other instrumentality than the artificial one of courts, if a legal injury may be said to exist. Alas, again, the insult to the honol of the two cities does not constitute an injury of sufficient gravity to be considered by any national court.

But if these suggestions seem the wild ragaries of imagination, let us take more concrete examples. The drainage of the city of Chicago pours itself out into the Illinois River, and diagonally across the state the current flows to join the purer waters of the Mississippi. Soon the flood reaches St. Lonis, and endangers the integrity of its water. supply. Shiall not every stalwart Missourian who 
feels his bosom beat with love for his State fly to arms, cross the Mississippi, and relentlessly fall upon the luckless citizens of the State of Illinois? Shall the health, the comfort, the prosperity of Missouri be ruthlessly attacked by a neighboring State and the injury not be wiped out in blood? Must the Missourian stand supinely by while the population of his State becomes decimated by disease set at rork by the carelessness of people alien to his State government, and whose actions have conclusively shown their lack of courtesy and civilization? Are not such people worse even than peoples whose skins are black or perhaps yellow? Is it not the high mission of St. Louis to carry civilization even to the banks of the Sangamon? Is it not part of the Missourian's share of the burden of humanity to teach the true gospel of the golden rule to the backward denizens of Pike, Cook, and Jo Dariess counties? Must not these questions be answered in the affirmative but for the fact that Missouri and Illinois recognize as a common superior an artificial entity called the United States, which forbids such war and relegates both parties to peaceful courts, where, with the assistance of bacteriologists, lawyers, and judges, the issues are fought out without the pomp and circumstance of war? Are re not indend living in a dull, uneventful age, and inflicting upon 
the young men of both States the canker of peace? But once again the logic of war is denied and the manly virtues remain undeveloped.

Yet another illustration. The State of Kansas contends that the waters descending from the mountains of Colorado should be allowed by Colorado's citizens to pursue their way, unvexed and undiminished, to render more fertile the plains of the Sunflower State. The vital interests of the States collide. Shall the interest of bleeding Kansas be allowed to suffer because of the selfish and grasping policy of the men of Colorado? Invoking the soul of John Brown as it goes marching on, let the Kansans march upon the sons of the Centennial State and slaughter them until they learn how to live and let live. Alas! once more, war, which, like poverty, is justified because we have always had it and the contrary is against human nature, is suppressed; and the great sovereign States of Kansas and Colorado are forced to bow to the dictations of nine men in black robes, only one of whom, and he by chance, happens to be a citizen of either State.

I have given you two imaginary and two actual illustrations of circumstances which, by all the books, would justify war. In two cases honor dictates, and in all four vital interests demand it. The only restraining thing is that the contending 
parties are, in each case, subject to the control of a judicial body. In vain could any of the States named declare their right to determine for themselves what was needed to satisfy their own honor or to maintain their own true interests. Always their neighbors insist upon their superior right to preserve the peace of the Continent.

But so little civilized are we internationally that books are written about the rules of war; that the right of blockade is recognized between nations; that, because of brawls with which no outside party has any concern, the commerce of neutrals is interfered with, the property of their citizens often exposed to the ravages of war on land, while neutral governments, unlike the onlookers at a street fight, who content themselves with making a ring about the contestants, accept limitations upon their own conduct made by the fighters themselves. Can we not learn that there is no more dignity, no more glory, about a national dispute, about a national conflict, than there is in a duel between two neighbors over the proper placing of a line fence?

And if the good of the community demands that the quarrels of neighbors shall be determined by a legal court, if the rivalries of cities and States must find in this country their settlement in dispassionate tribunals, why should there not 
be, judicially at least, the United States of the world, with a tribunal capable of passing upon all international questions without restrictions?

We may here pride ourselves on believing that we are going with the swing of international feeling; that with the spread of intelligence, with a greater recognition of the equality of liuman beings, which in the last analysis denies the right of one man to require another to sacrifice his life and property without just cause, duly ascertained by cold and competent tribunals, there must come a time when war will be looked upon as a crime. The stars in their courses fight for us.

Let it not be said that I am inappreciative of the dignity of war and of the importance of the causes leading up to it. War has no dignity. It offers a tragedy and a farce. With the tragic element we are all too familiar. With the farce of it all we are less familiar, for it is one of the obvious things-so obrious and so accustomed that, like the movement of the earth around the sun, eons of time pass by without its realization. What can be more farcical than that human beings should be dressed up in gold lace and waving plumes to go forth to slay other human beings in waving plumes and gold lace? Why should bearskin shakos be used to add ferocity to their ensemble? Why should the common people, whose interest in the 
matter is nil, make themselves food for powder, all for the benefit of the few whose tinsel decorations blind their own eyes and those of the beholders? And why should parents who love their ofispring rush into opportunities of bequeathing to them legacies of national poverty and debt as the result of a display of passion on the part of the fathers? And when all this is the work of sentient human beings, may we not wonder over their effrontery in speaking of themselves as reasoning creatures? Are nations so rushing into conflict wiser than the mad bull in the arena that with lowered head dashes upon the sword of the matador? May we not conceive of a real philosopher looking down with wondering and puzzled contempt and amazement at our bloody antics over baubles?

For as yet we are but children and have the ways of children. Between the childish disputes, " It is," " "It isn't," or "I want to swing," " No, I won't let you swing," and the average differences between nations leading to war, there is in essence no distinction,--nothing save the age and number of the disputants and the consequent variance in the objects which interest them. Relatively, the contest is unchanged, and equally it should be adjusted without killing and without the slow sapping away of life through taxation. 
But if you tell me that such doctrines as I have tried to set out are opposed to patriotism, let me say to you that patriotism is not a fixed but a growing term. When the first Englishmen planted themselves on the shores of Massachusetts Bay, their patriotism was bounded by the fringes of woods concealing Indian enemies. Later it meant a special sense of duty to those within the widening boundaries of the province. Yet a few years, and with the birth of a new nation, all who lived within the bounds of the thirteen original States were recognized as their brothers. Then, by leaps and bounds, it came to pass that the teeming millions of human beings from the Atlantic to the Pacific represented the solidarity of the country, and all were recognized as brothers under a common flag, and between such brothers war was a crime, and all troubles to be determined in a peaceful manner.

But one step is left. We have to recognize the brotherhood of the human race and the infinite crime of bloody contests between members of a common family. When the day of such recognition arrives we shall love our immediate neighbors no less, and for them reserve the special offices that our finite strength limits us to giving to the relatively few, while the narrower features of the patriotism of today will be swallowed up in a broal consideration for the rights of humanity, and all men will be brothers. 


\section{CHAPTER XI}

ESSENTIALS OF PEACE AND WAR

"From battle, murder, and sudden death, Good Lord deliver us." Thus saith the Litany. We forget that without our active assistance in the correction of evils which lead to battle, the pious ejaculation of the Litany becomes no more effective than the turning prayer-wheels of Thibet.

But we have done more than to pray nervelessly for peace. We have organized society upon society whose avowed purpose has been to promote the cause of peace, and with them all we have paid little attention to the essentials of the thing we sought for. Thus it has been that all of our work, either in private association or represented by formal resolutions of the Massachusetts State Legislature, of Bar Associations, of the Congress of the United States, has amounted in practical result to little beyond the returns from our thoughtless repetitions of the Litany.

No one has offered dissent to any of our resolutions or protested against the purpose of our societies. Even the most pronounced militarist will aver a love for peace and will declare that he is in favor of arming to the teeth to maintain peace and prevent war. In fact none but a degenerate 
wouk glory in gas-eaten human bodies, in torn limis, in drowning men and women, and in all the other varied forms of injury to persons and destruction of life war offers us.

With all our praise of peace and denunciation of war, we find Europe in ruins. Each international giosis-oad offers an opportunity for conflict. Meanwhile America punishes itself by expendingr 93 per cent. of its amual ontgo for past and prospective destruction. We go on believing that a private killing is murder, but the taking of human life on the order of a group of men called a Congress, a Parliament, or a Cabinet becomes sanetified under the name of Patriotism. Despite the frills with which we have decorated international action, analysis shows that we have taken but trivial steps to delay pliysical fighting over things which nations ordinarily regard as material.

Analogies are unsafe, and yet perhaps we may imagine one not without truth. Suppose that one hundred years ago legislatures and associations had conmenced to tell the world that health was beautifnl and disease painful and disagreeable. Suppose men had marshalled themselves under bamners proclaiming to the breeze "mens sana in corpore sano." Suppose that our ancestors and onrselves after them had all mited in declaring that health kept for a longer time the bloom of 
youth upon the cheek; increased individual comfort; led to a higher morality; lengthened lifewould not every saloon-keeper have agreed and every opium dealer hare wished the apparent morement Godspeed even as now militarists cry aloud furiously for peace? Suppose that during all the time this was taking place our ancestors and ourselves resolutely refused to examino into the causes of lisease; took no steps to clean up slmms; did not drain swamps or stamp out the mosquito; failed to fight darkness with light or point out the dangers of the nse of opium or alcohol,--would human life have been lengthened or made more comfortable by virtue of all these fine resolutions? Has there not been a close analogy betwcen the conduct of our leaders of thought in this country with relation to peace and the imaginary conduct which might have beon indulged in during a like period by the adrocates of health? Solemn resolutions in favor of inter.national order parallel solemm resolutions in favor of health and material wellbeing. Refusal to examine into the causes of international disorder parallels refusal to seek out the causes of disease. The swamps, mosquitoes, and vice our scientists have sought to limit and destroy. Their like internationally remain, so far as we are concerned, unknown, unrecognized, or at least untonched. 
By the univer'sal line of conduct in practice assumed, we and our ancestors have appeared to regard peace as something to be attained and assured by a kind of fiat. We have put it on the same plane with Direct Legislation, or Woman's Suffrage, or Proportional Representation or other schemes of administrative reform, overlooking the fact that it was vastly more subtle; that it was a product and not self-existent; that it could only be created and preserved by circumstances favorable to it. Wre have thought that we could sow broadcast the seeds of war and after the plants appeared, successfully graft upon them the olive branch of peace. As well might we hope to graft the fig upon the thistle.

Sometimes in specific instances we have said that lust for territory or desire for access to the sea were causes for war, and unthinkingly have looked on when nations quarreled over the possession of natural resources. We have never particularly analyzed these causes to find whether or not, granting present national and international conditions, there might have been some entirely understandable excuse for them. We have not concerned ourselves with their removal.

If we had stopped to consider conditions in our own country as offering an international parallel or suggesting our duty toward our neighbor in 
the cause of peace, we might have pointed out an antidote for the bane of many wars. Does Rhode Island particularly concern herself over the fact that her territorial limits are restricted? Is there a citizen of the State who would be willing to lay down his life or ask his neighbors to lay down their lives to add one or one thousand miles to her territorial jurisdiction? Is there a citizen of Vermont who is distressed over the fact that Vermont has no immediate access within her own jurisdiction to the Atlantic Ocean? Would any denizen of New Hampshire be willing to fight, supposing it otherwise feasible, against citizens of Pennsylvania because of a desire to obtain for his State direct control over beds of coal and iron. And yet these several suggestions involve extension of territorial limits, access to the sea, possession of natural resources, which are made the frequent cause and excuse for international conflict. Anyone of them would be unthinkable within our nation, and, were justice to prevail between nations, would be equally unthinkable internationally.

This American peace is not due to the fact that we have a common executive, a Congress, and a Supreme Court, useful as all of these instrumentalities may be. It exists because any citizen of the United States equally with any other citi- 
zen has a right in perfect freedom to pass State border's with all his family and property; to import and export from place to place within the limits of the United States any sort of property he pleases without hindrance from any State authority; to gain access to and from the seas without any local interference whatsoever.*

It is quite beside the mark to say that national or international executives, councils, or assemblies with ample paraphernalia of courts, will insure peace. Nothing will attain this end save justice and equality, not merely as between nations but also as between the individual members of nations in their intercourse with those who are citizens or subjects of another jurisdiction.

We have the proof of this in our own experience. With as nearly perfect a sstem as exists in any comntry of executive, legislative and judicial authorities, when the essential nation-wide injustice of slavery existed, we forget all else and there occurred the war between the States. Likewise we may expect wars to continue despite all leagues, associations, Hague Courts, international police, or whatever agency may be imagined, mless we study resolutely the secrets of international justice

* It is not necessary to discuss such minor limitations of intercourse as affect health or prevent internal disorder. 
and cure injustice. This we have scarcely commenced to do.

If we would maintain peace, therefore, we must commence by following the fashion of the health society which would very speedily have abandoned the denunciation of yellow fever, tuberculosis, and smallpox for the isolation of the germs.

We have so far remained in such complete igno:ance of the subject that we have not even discovered where peace ends and war begins.

We treat war much, in International Law, as if it were a bolt out of the blue; as though it were something not within the control of men, but which comes upon nations as a mysterious epidemic sweeping all before it. We look at its ripened fruit of physical combat and we forget that this product does not exist save as the result of a long course of development. We carefully sow its seeds in injustices toward and special advantages taken of our neighbors. We fertilize and water with our suspicions, jealousies, avarices and desire to submit our neighbors to our power, and then, allowing the plant to develop, we suddenly discover we have the flower and fruit. No one would so treat the upas tree, if it possessed the qualities travelers have given it, but unintelligently we cultivate something infinitely more deadly. We bet- 
ter the ancient saying "In time of peace prepare for war," for in this period we energetically generate war itself.

Let us illustrate by a single example the point in mind. We say commonly and roughly that war opened between Germany and France in August, 1914, this because the official killings date from such period. Without undertaking to trace the struggle to its more obscure beginnings, with greater show of correctness, it could be said that the war began in 1870 with the taking of AlsaceLorraine by Germany and that the development of the plant to its greatest perfection had covered a period of 44 years before the perfect fruit-physical war-was gathered.

While the taking of Alsace-Lorraine was in itself a political crime involving also undoubtedly much personal discomfort or injury, if individual suffering and political control alone had been involved the consequences might not have been serious.

The provinces taken contained much mineral wealth, useful theretofore to France, but thereafter devoted to the special benefit of Germany. The latter pursued with narrow selfishness the plan common to nations of treating the wealth unfler their immediate political control as an instru- 
ment to be employed to their exclusive benefit or rather in a larger degree to the benefit of a small circle of their more privileged classes. Taxes and tariffs were adjusted to this end. This wealth which, if nature teaches us anything we may believe as intended for the benefit of all humanity, was thus appropriated by a few and particularly employed for their advantage within the national limits.

This course, so natural as nations are now educated, involved tremendous and disastrous consequences not alone to Germany but as we have seen to the entire world. Knowledge that it would be taken precluded friendship between France and Germany. From that time on Germany with guilty conscience, feeling the necessity of rendering herself capable more completely of overthrowing the country she had immediately wronged, prepared for the certain physical conflict and France followed in her train. Each advancement on the part of one country in the art of civilized slaughter was met by further progress on the part of the other. At every point, military, industrial, political, each nation, without tracing its steps to their ultimate conclusion, injurious to itself, sought to hinder and prevent the normal development and expansion of the other. German industrial and political relations with Austria became closer. France created 
more intimate associations with Russia and England. If France desired preponderating influence in Morocco, a German man-of-war offered an implied threat, to which threat France, England and other countries responded essentially in kind, if their conduct were less blunt.

If Germany desired larger industrial and economic development in Turkey and the valleys of Mesopotamia, allies of France stood in her way. The French peasantry were ready to supply their hard-earned franes to the development of military power in Russia, and Germany answered by levies on capital to meet the situation. France riposted with a three year's' service law. In every moral (or shall we say immoral?) sense were they not at war even though no blow was struck?

If, therefore, we are to address ourselves to the great problems of war and peace, can we do so without a revision of our definitions of these two opposing international conditions?

Imagine that during all these years the artificial barriers between France and Germany had been non-existent; that Germany, laying aside all chauvinistic patriotism, had granted France free access to all German markets and materials, and that Cermany had enjoyed a like privilege in France; that England and Germany on equal terms with every other nation and at their own 
option could have entered or refrained from entering upon trade or commercial exploitation in Morocco, Mesopotamia, and elsewhere; that the various countries had not arrayed their manufacturers and merchants against those of every other country and that merchants and manufacturers had possessed forethought enough not to have asked governmental aid, would we not, despite a political change affecting Alsace-Lorraine, have escaped 44 years of incipient warfare and an industrial and political warfare to extend into a future far beyond our ken? Would not the United States have been saved the lives of 100,000 of its most promising young men, avoided thirty billions of dollars of indebtedness and the expenditure of untold billions hereafter for excessive armies and navies?

If the giving up of special national monopolies; if refraining from tariff and other taxes not capable of ethical justification; if the abandonment of selfish advantages for the nationals of individual nations; if the practice of justice would have meant, as in the long run it would not, sacrifices by individuals among the several nations, had it not been better to have stood such sacrifices than to have risked the civilization of the world on the battle-field?

We have given heed to the demands of many 
small nations for independent govermment. We have done so without stopping to consider whether or not their creation as separate entities was calling into existence new trade barriers; new obstacles to natural growth; multiplied forms of national selfishmess, and therefore offering new causes for war.

We have been as blind as the medicine men of a more savage age who sought to cure disease when it had broken out virulently by their incantations and their dances, but who were ignorant of the fact that there had been perhaps long antecedent conditions of ill health, which they had passed unobserved. They saw only the final outcome, and knew nothing and never sought to inquire concerning the obscure origins of disease.

Our point of approach must now be very different and much more radical than has been represented by all of our resolutions in favor of peace. It must address itself resolutely and persistently to the study of the causes of disease and not to declamation against its existence or attempts to prune a poisonous tree.

Chattel slavery was not abolished by regulating the quarters to be occupied by the slaves or by allowing a slave to testify in court. The axe had to be laid as it were to the root of the institution. And in like manner our thought must go unflinch- 
ingly to removing the causes of war and a redefinition of war and peace on the lines herein indicated will materially assist us in our work.

We denounce the immoralities of war and feel ourselves better citizens by so doing. We might as well denounce boiling water for scalding. Te do not denounce the various immoralities internationally of which we are guilty in time of peace. These when practiced for sufficiently long time furnish the explosives creating what we call war.

War like business depressions moves in cycles. In business when our over-reaching practices have continued long enough and the strain touches the breaking point, we become engulfed in a panic or depression. Nothing in nature compels the cycloidal movement in business and likewise nothing in nature compels a war cycle. The origin of each is found in defects of human conduct, the germs of which are perfectly capable of being isolated and treated. 


\section{CHAPTER XII*}

SOME TENDENCIES PRESSING TOWARD JUSTICE

AND PEACE

"The object of International Law," says the pacifist, "is to insure peace as the highest good." "War is inevitable," says the militarist, "because with its foundations deep in human nature it may not be avoided." In a practical way both positions involve an element of error, at least at the present time. Law has as its truly beneficent purpose not peace but justice. Peace is a by-product of great value, certainly, but the fact may not be ignored that justice has ever seemed to men more important than peace, and that without it peace can have no firm foundation.

Turning to the attitude of the militarist, we may question if there be an immntable quality in human nature making mankind in masses either peaceful or warlike, merciful or cruel. We may doubt if it is necessary to change human nature to destroy the trade of the warrior. We do know that one of the fairly fixed qualities of human nature is its ability to change its manifestations according

* The larger portion of this chapter was published in 1911 for the American Assoeiation for International Conciliation, by whose courtesy it is reproduced here. 
to its surroundings. We have in us a good desl of the chameleon. If men are taught from youth up that war of itself and as an end in itself is righteous and commendable, they will be militaristic, and it will be said that their human nature is warlike. If the fellows of the same man are brought up in pacific surroundings the reverse will be observed. To secure this transformation does not require the processes of the ages changing something inherent and fundamental. The inclination of men to fight can be materially changed -increased or diminished-within a generation or two. We may believe therefore that viewed as a practical proposition, the basis of the reasoning of the militarist is not sound.

If we discuss war as an end in itself, are there elements tending so to change our surroundingsour relations with our fellows-as to render war less excusable or desirable? Despite the will to power; despite our exaggerated and overbearing patriotism, in the like of which other countries than ourselves are also running riot for the moment, there exist influences tending in this direction and which in the long run must play an important part in enlightening what goes under the name of International Law, and so alter our absurd and bloody practices. These will make us at the 
same time alvocates of justice, which will come with its handmaid-peace.

At the entrance to the bridge leading from the little German town of Klein Basle over the Rhine to the Swiss eity of Basle, there is, or was, until recently, a bronze statue, so grotesquely arranged that upon the stroke of the hour, it made a contemptuous grimace toward the larger place, thus expressing the distrust and hostility felt by the inhabitant of Klein Basle toward those of Basle.

The illustration is typical of the feeling in the beginning of the people of different neighborhoods toward each other. Those separated by a river were enemies. The people beyond the mountains were debased and perverted characters. The villagers across the lake had no saving virtues. Those over the desert or the other side of arms of the sea were scarcely of the same race. If one traveled a few miles he was among pagans and heathen. It he journeyed among men of a different color he became a foreign devil. If men were powerful enough, they enslaved first those of their own race but of another neighborhood, and with rising civilization those who were merely of a different color. In either instance, they degraded their fellows and denied to them human or divine attributes. 
But despite all our narrowness and littleness, there came to grow a sense of truth, opposing all our prejudices which themselves arose out of our predilection for the things to which we were accustomed. We appreciated, dimly and imperfectly at first, then more clearly, that aiter all, in the measuring of human qualities, notwithstanding our natural preferences for our own, the characteristics which distinguished our neighborhood or nation or people might be balanced by those which a different environment or experience developed in others.

The education or qualities which under certain conditions have brought to us success in life may, if we be quickly transported, count for little or nothing under other suns. The Englishman, suddenly finding himself in a desert, may perish for the want of special training, while those whom he calls savages, but who are only differently educated, may there find sustenance and comfort. The moral qualities which enable each individual white man, conducting himself selfishly, taking no thought of his fellow, to live with satisfaction, find a substitute in the generosity of the man of the wilds, who knows little of individual ownership, but fully recognizes a natural obligation to his less fortunate fellows. The austerity of one race is perhaps offset by the courtesy of another. 
The matter-of-fact man or nation finds his or its counter-balancing quality in the imagination or art-sense of another.

It turns out, on thoughtful examination and widening experience, that no one nation is at all times sufficient unto itself. As this knowledge comes, not alone to one country, but to all, the need of living together amicably and the appreciation of the labors of our fellows placed by force of circumstances under different surroundings must with time girow stronger and stronger. We shall perceive that the words of Goldsmith, spoken of nations, have a broader meaning than he had in mind when he wrote:

*** if countries re compare

And estimate the blessings which they share,

Tho' patriots flatter, still shall wisdom find

An equal portion dealt to all mankind.

Many things tend toward unity of feeling among nations. Every traveler who crosses the Atlantic, whether he start from the East or from the West, brings about a better understanding between nations. Every railroad train crossing a frontier, every ship plying over separating waters, every cable conveying news from foreign nations, every exchange of letters or business, every book of travel, every useful or agreeable article of foreign production, every sale of our own produce or manufacture to foreign lands, is a civilizing agent, 
containing in itself the germ of destruction of old national prejudices and hates. In our land the traditional stage Irishman or German or Jew is disappearing. If we still laugh at the representation of a foreigner in the theatre, it is not empty ribaldry, but only the amusement we may indulge in over the foibles of our best friends. Indeed, we may sympathize with the pathos of the position of the foreigner.

We borrow from other nations, sometimes, it is true, the worst, but more often the best, in them. If England politically gives us Adam Smith and John Stuart Mill, we return our ideas of political machinery, and from an American author LloydGeorge has found inspiration for certain of his most philosophic utterances. The French Pasteur and the German Koch teach us truths beneficial to humanity, and the death of Tolstoy left a score of nations mourning. A better knowledge of Confucius and a sympathy with Chinese aspirations causes us to regard the individual Chinaman with a ner forbearance. The deaths of Ambassadors furnish us opportunities for placing American warships to a more friendly and therefore a saner use than was ever designed for them.

There is a leveling process going on among nations-leveling in more senses than one. We borrow from each other, as shown, institutions, 
literature and customs, sometimes appropriately, and sometimes, it is true, making misfits, with grotesque consequences. At all events, we grow more and more alike in externals, which, sooner or later, in greater or less degree, affect mental attitudes and attributes. In the end the railroad men of lines between New York and Washington, Joppa and Jerusalem, must resemble each other in their habits of mind and moral qualities more than did their great-grandfathers. The parliamentarians of T'urkey and the Congressmen of the United States have infinitely more in common than their forefather sheiks or attendants upon New England town meetings a hundred years ago. The bonds of sympathy between them have become infinitely stronger and have multiplied.

We look with pitying wonder or amused contempt upon the state of mind which made men separated by a slight obstruction natural enemies. Travel, education, the press, which daily summarizes the striking events of a whole world, make the whole world kin and compel a sympathy for, and forbid our indifference to or rejoicing over, the sufferings of any portion of mankind.

Day by day and year by year this sympathy grows. Our business, using the world broadly, is no longer merely the business of our little neighborhood, our eity, our State, our nation. It is the 
business of the wide world. We cannot calmly regard injustice to a Chinaman or Jew or Armenian or Spaniard or black man. We mar not, without accusing consciences, as a nation inflict injustice upon another nation. Our actions must measure up to the standard of justice required by all the civilized nations of the world.

The self-respect and the desire for the respect of others which prevent a stronger man from committing acts of physical oppression upon a weaker one is beginning to have its effect upon the dealings of a great nation with its smaller brothers. At least their own citizens grow more and more critical. And this feeling grows, as I have indicated, out of the regard each has for the other, proceeding from the realization of the benefits each brings to the common service of humanity. It is easier to be brutal to a slave or one umprotected by public opinion than to injure a co-worker who brings to our common store experiences or qualities mutually advantageous. We are building up humanity to a common level, and making it generously alive to the interest of all, irrespective of race or nation.

Buckle was unable to find that human nature had materially changed in two thousand years. Fear of consequences will no more control the mad man or nation of today than it controlled the like 
in ages past, but the things which provoke anger will disappear. The democratization of the world is minimizing the effects of the private ambitions of the rulers. The development of the masses, their growing intelligence and intercourse, is making them regard all men simply as coworkers-friendly, not hostile xivals-in the fruitful vineyard of the world. If all this be true, the world is preparing itself for a larger measure of justice and peace.

Human nature is not changing, but politeness and the underlying ground of politeness, sympathy and recognition of common needs, is growing more universal. Instead of fear of the consequences of war leading to peace, a better comprehension of the equality of the individual is the real pacificator. A hesitancy to condemn men unheard to suffering and death-men whose rights are equal to our own -is the mainspring of modern action. That this feeling finds scant proclamation signifies little; that it exists, and is growing with mparalleled rapidity is the most important thing in civilization. Right-doing between nations must become the practice, as contempt for the national wrong-doer becomes worldwide. 


\section{CHAPTER XIII}

BASIS OH A DEMOCRATIC LAW OF NATIONS

When Watts, as the story goes, watched the cscape of steam from his mother's tea kettle, he discovered a theory of expansion, from observing the little volume of water converted into steam. This theory was no whit different from that today ilhstrated through the boilers and engines driving the largest ocean liner. All the principle was illustrated in the little utensil of the kitchen. It remained but to create the machinery, a work which has gone on with increasing perfection for 150 years. Our writers of International Law, finding: States in existence when their studies began, have forgotten all about their humble origins from which principles might be dednced. Seeing them with all their enormous crndities and violences, writers have sought to regularize the conduct of States by artificial rules. They have allowed themselves to be influenced by the size of the object before them, as if size alone created rights and duties. With this misconception controlling them they have created a crooked International Law. Their action has been quite analogous to that of a man who, finding a tremendous machine capable of being run by steam, wonders why it does not operate when he floods it with water. The living spirit not there, the machinery can not function. 
It is impossible to arrive at any just conclusions with regard to International Law except one discover its true spirit by considering in some degree the units of society and applying to the nation the principles which must be recognized as controlling its units. Stated in a few words, all the International Law that has any right to be may be summed up on the lines of the proper conduct of an honest man, a good citizen, and if you will the head of a family. This for us is the steam as it escapes from the tea kettle. In so far as International Law as applied between nations has departed from this, exactly to such an extent has it poisoned the relations of nations, and with its connivance untold miseries have been inflicted upon the human race.

Let us consider then critically for a brief space what we expect of the citizen of whom we have spokn. He must be faithful, of course, in the performance of his obligations. $\mathrm{He}$ is forbidden to murdry and to rob. He can not by chicanery undertake to obtain the goods of his fellows. Under the plea of protecting or advantaging the members of his own family, he can not by any subtle manoeuver seek to gain the upper liand of another. He has learned to curb his temper, and, offending no one by trick or device, conducting himself as a [nonteman, he is not likely to be disturbed by 
others. Despite his strict attendance upon all these requirements he may be imposed upon or cheated, but it will not occur to him as within the limits of his character to respond in kind. He will not line his belt with revolvers and swagger up and down the market-place.

If these be among the criteria of the good citizen, we may ask why, when for reasons of convenience men are united together into a nation, all these principles should be laid aside? If International Law is to make us over into citizens of nations frank with themselves, all will come to preach and practice these rules.

We may safely say that the best begimning we can make toward the institution of real International Law is to try to make over ourselves into a fair-dealing nation in the fullest and most exact meaning of the term, modeling its conduct upon that of an upright man. When we have done this our work will be recognized and will have its inevitable influence upon all the nations of the earth as a "good deed shines in a naughty world."

But you say we are honest. We do pay our debts. We comply with our national engagements, usually, at any rate. We meet all the requirements. Sometimes this may be true, but how far short we fall! 
We male, years ago, in the iour quarters of the globe, a display of our naval strength which invited some of the weaker nations, through fear or through example, into military expansion which nearly ruined them. We made Japan feel her inferiority on the seas and pushed her further in a race for naval supremacy which has had a tronendously injurious effect upon the toiling masses of Asia and has reflected back upon us as justirying our increased naral expenses. Was our behavion in any wise different inom the indecent comse of a bully parading his artificial and natural strength before his fellow citizens?

"We adopt in oul custom-honses a system which interferes with the trade of others with us, and, under the guise of protecting all of our citizens, wives recuniary advantages to a few at the expense of the many. We injure the free, open and natural development of the work. Whe make of ourselves in this respect a bat neighbor, and one who encouragrs some of his children to gain advantages if possible at the expense of the others or at the expense of the neighbor's children.

If T'arifa levied toll on commerce in and ont of the Mediterranean; if Algiers did the same, with failure marking their efforts, are we justified in thinking our more refined endearors will win us the prize and will give us a crown of laurel? 
We seek by other policies to build up America to the disadvantage of other nations, deflecting industry and capital from those pursuits which would be naturally and properly gainful, into others which may only be gainful through coddling by the government.

The porrer which we possess over the Panama Canal-a power in the exercise of which we shonld only act as a trustee for the whole world-we try to turn to the benefit of a few of our number, seeking to deceive ourselves with the idea that all Americans share in the advantage, and, as if this justifies us, that the only person to suffer is the foreigner.

Although in this regard our offenses have been less than those of other great (i. e. large) nations, we send our navy and marines to protect or to advance American investments in foreign countries, -investments which as a nation we never asked them to make,-while as a nation we would prefer a natural home development rather than one which must be propped up by bayonets.

We have made ourselves feared but not loved in every country south of our Mexican border. We have ignored nationally important teachings of good international citizenship. Our attempts to take advantage of our neighbors have violated principles of righteous International Law. 
In all of these and a dozen different ways we have raised up and are continually raising up for ourselves enemies in every quarter of the globe, enemies who would accept our downfall with perfect equanimity if not delight.

If our nation is a bad citizen of the world, we can not excuse ourselves by saying that others are as wrong in their actions as we are. What they do is primarily their affair. Our business is to do right.

If we would know whether many things we have done are right, let us ask ourselves whether we do not experience a feeling of resentment when any of them are practiced in any degree by other nations toward ourselves.

Have we ever put to ourselves this simple question: Do we do the things just mentioned because we expect to gain for some or all of us a selfish advantage over the citizens of another nation? Do we ask ourselves whether or not the gaining of an advantage or the attempt to gain one by such actions is vain when indulged in with the idea that in the long run profit at the expense of others is possible?

Is the man honest who seeks to obtain for himself or family an advantage which may only be had through an interference with the natural rights of 
another? Is the nation which pursues such a course an honest nation? The individual who follows such lines of action may for a while, perhaps even for his lifetime, reap pecuniary benefit. He feels his punishment in the want of public confidence and esteem; in the exposure of his motives; in suits in court, and it may be in terms in prison. The last penalty will find its analogy in war', so often the result of unrighteous courses pursued between nations. With punishment in view, for it is inescapable if the process be continued long enough and be sufficiently extreme, may we not ask ourselves whether it is worth our while as a nation to be less honest than we expect an individual to be?

To none of the actions of which we have spoken does the International Law of today impose a negative, and yet the commencements of International Law must concern the actions of the nation. Just as the individual in society is required to do no wrong if he would escape the law, written or unwritten, so must the nation. We are justified in believing, therefore, that the International Law of today is without substance, for it pays scant attention to the duties owed by one nation to its fellow-citizens in the society of nations.. Without this it must remain a vain science -no science at all. 
The course which has been suggested is not an easy one to pursue. We have to lay aside the apparent (not real) monetary adrantage of today to escape the certain revenges of tomorrow, but we delude ourselves with the belief that tomorrow may never come. In indulging in this delusion, as has been heretofore pointed out, we ignore all the lessons of history. We forget that we may not even levy a tariff without meeting a counter tariff from some other nation. We may not, in fact, maltreat the humblest nation for the benefit of a few Americans withont at some future day an enemy finding through it our vulnerable heel.

Fatuously we say "It must never happen again,' and with all the strength of our mercenary little souls turn to our daily business of sowing the seeds of war and clinging to our fool's goid.

We may indulge in the thought that democracies will do no wrong, but experience is against ns. Besides this we need not forget that democracy is in the making. It is suffering trom nnforgotten feudal practices. Democracy did not spring full armed from the brains of the men of our American Revolution. It is as yet but a child, subject to many rlangers and many diseases, and having inherited many evil tendencies from its prerlecessor's.

We have lost 100,000 meis in a European war 
which we have fondly called a war for democracy. If they have died in a war simply to maintain and preserve the limited and halting democracy we have today, then assuredly their sacrifices have been in vain. The thing for which we, if we are thoughtful at all, feel that they have perished is to insure a chance that the democracy of today shall have free scope for its natural development. We know that it is now disfigured and distorted by inefficiencies, corruptions, and ignorance, but we believe that it has in itself sufficient reserve of health and healing power, given a free chance, to bring about a development which would compare in its friture grandeur with that of now as the mightiest engine in existence or conceived of at this moment compares with the first crude attempt of Watts to put to work the live force of steam. To this end, of course, our dissenters and our critics of government must be encouraged instead of hampered, as is so often the case. Even in their biunders and misconceptions there may always be some element of truth which may not be disregarded save at peril to the Commonwealth.

Let us turn, however, to the international field. Ilere we find the aristocratic idea which subordinates the man to the State rampant in its most objectionable and terrible forms. International Law needs the application of democratic principles, and 
this application must begin with a careful survey of the relations of the individual man to his fellows. With this thought in mind we must continue our examinations until we reach the largest conceivable association or league of nations. When we do this, we shall find that we simply carry to their ultimate the principles of democracy as we master them. We can then develop readily for their use the most competent machinery our knowledge enables us to create and use.

This method of progression has not been followed. The man and his rights and duties have been lost in the nation, to which we have ascribed as its perquisite abnormal and inhuman qualities. When, however, guided by the spirit of democracy, we learn to apply it to larger and larger groups of men, we will write a fresher and purer International Law than has yet entered into the dreams of would-be scholars.

We have devoted our thoughts to the machinery of international relations. We have proposed courts without principles to guide them. We have devised administrative agencies without any comprehension of the directions in which they should work. We would create a Frankenstein monster perfectly capable of destroying us, because destitute of thought or principle or any well-grounded restraining influence. The results of worldwide 
stupidity and rascality have been made manifest on a thousand fields of conflict within the past few years, and are continuing to plague us in this time which we call one of peace.

In our democracy within States, we require, theoretically at least, equality of all men before the law. We exact equal justice to all. We compel equal submission to the mandates of the law. We allow the individual the equal voice in the making of the rules of conduct his status as a man justifies. We believe that our aspirations in these respects should extend to all men. And yet when we pass over the imaginary lines marking our national jurisdiction, and deal collectively with groups of men associated under another nationality, we collectively deny to them those rights and privileges accorded within our own borders. We become judges in our own cause. We claim for ourselves the privilege of hampering the development $0^{\text {? }}$ others lest they may progress faster than we do. We impose our will upon them. With these denials of justice and of the democracy to which we render freely lip-serrice at home, we wonder that war continues.

Since 1776 America has been exercising a wonderful influence upon the peoples of the world. How profound it has been was not appreciated by the governments of the great nations. Their rul- 
er's liave but just welcomed us as a World Power', and imrited us to share the world with them and according to their principles. The brazen and painted materialism of their older civilization now embraces our heretofore somewhat austere youth in loving dalliance. We are drinking deep of the blood-red wine of Hayti and Santo Domingo. Our "spheres of influence" in Mexico and Central America are our gambling tables, with human beings as our "chips" and our dice fashioned from the taxes on our people. We are becoming world ruffians like the rest and influential in the world of force.

In all the ways we have described we are sowing dragon's teeth and from this seed we expect a croy of peace. The next generation or two will reap the harvest we so carefully prepared for them, but what have our grandchildren ever done for us that we should care for their wellbeing? And meanwhile all written law is silent, or at most, whispers, and the lessons of unwritten law are unheeded. 


\section{CHAPTER XIV}

RESUMÉ OF OUR CONCLUEIONS

We have traveled swiftly and it may be superficially over much ground. In approaching the end, it seems advisable to make a summary of our progress.

We have found that laws within the nation were properly divided into those of convenience, involving no particular element of right or wrong, a formal decision being given as to them for the benefit of all; next there was adjective law which we may roughly say represents law in action, and relates to the method and manner of enforcement of all other legal directions, and lastly was that law which involved fundamental ideas of right and wrong. We have discovered that this third branch of law has been developed from time to time as mankind has learned that the consequences of certain human actions were injurious to the social wellbeing and hence wrong. It has been deduced that they represented infractions of that natural law which envelopes society from the instant of its formation. Thus we have concluded that if, by way of example, murder instead of being socially a destructive act had been found beneficial in its consequences, no law would have forbidden it, but 
being socially mischievous mankind perceived it violated a fundamental law later framed in words.

We then turned to the field of International Law and found it unsystematized. As in the state, there exists conventional law as represented by a great variety of treaties relating to matters in themselves indifferent. These are ordinarily observed by nations. We found also that there was an adjective law which concerned itself with the methods of bringing into force the treaty provisions referred to as well as in some extremely rare cases carrying out what we next styled true International Law. We were perplexed to learn that the students of International Law up to the present time had not particularly coneerned themselves with the fact that there is a right and wrong in international affairs or that the violation of rules of right internationally results in difficulties between nations. They harl not, in short, traced back acts injurious to the society of nations to the real Intermational Iaw which had been bioken, although such law had been demonstrated to exist through the effects of its violation.

In our search we have fully recognized that if we would learn what true International Law is, aside from earily acepted conventions, we have to discovel the relation between action and reaction as illustrated by the conduct of nations between 
themselves. International evils existing, we agree as a fact that some law, even though unwritten, is being violated.

Finding in the manner above indicated of what International Law consists, we have asked next the question whether there can be such a thing as the laws of war, discussion with relation to which plays so large a part in books of what aro called International Law. We were at once forced to the conclusion that it is as impossible to systematize war as it would be to systematize disease; that the laws of war are grounded on no ethical reason; bears no relation to right and are incapable of enforcement. At best they are but temporary usages, without binding force.

In further consideration of the subject of accepted International Law, we have found its origin among the immediate servitors of kings, and that it is based upon the theory of kingly sovereignty, a theory which is inconsistent in itself, and, in the present state of the world, highly anarchistic.

We have discussed the meaning of "national interests," finding that men have been deceived by a word and that the so-called national interests are simply the interests of a few men, who for the time occupying positions of influence and importance within the nation are able to control in a large 
masme the operations of the government. We were led to suspect from this consideration that at present the control of democracy over foreign affairs scarcely exists, although the democratic theory must prevail between as well as within mations if the interests of the common man instead of the interests of a few are to dictate the course of human affairs.

This brought us back to the further consideration of the nature of International Law. We found that from being the simple thing that it should be, it has been made complex; that its professors being without imagination have never understood that there was a eomparative jurisprudence offering a great field for their thoughts and a solid fommation for the science they profess to teach. 'This law controlling within the State furnisherl the rule that whatever was wrongful infrastate, must of necessity be wrongful interstate. In this eomnection we indicated the manner in which the true student of International Law must hereafter gather together his data, from which data Ho will be able to deduer in detail the basic principles with which he must have to deal.

l'ursuing our subject forther we proved that the same theory which has been worked ont within the nution cstablishing individual rights would have to funish us the working basis of International 
Law; that proceeding in this line we shall find that the victor has no right to control the lives or properties of the vanquished; that the nation superior in power is not justified in exploiting the inferior nation. We have shown through different examples that imperialistic adventure carries such punishment as to demonstrate its antisocial international characteristics, and therefore its want of basic right in the laws of nations.

We pointed out the inefficiencies of international courts so far organized and the fact that it is necessary for us to have a working basis of lawa worthy end to which to work-before we need concern ourselves much about the instrumentalities which are to carry it into effect.

We dwelt upon the fact that under existing corditions nations are determinedly opposed to submitting to arbitration matter's affecting their honor, rital interests and independence, but we showed that these sre the very things which should be the subjects of judicial examination, competent rules of law first being established.

The essentials of peace and war have not been overlooked, and we have indieated that our definitions of these conditions must needs be revised; that during long periods of so-called peace we were in fact engaged consciously or more often unconsciously, and as actively as we knew how, in ir'- 
ritating assaults upon the prosperity of other nations, and that only by an abuse of language could such a period of time be termed peaceful.

We have pointed out that mere resolutions in favor of peace are not more than pious ejaculations and that the standpoint of the peace advocate should be that of a student of the causes of diseases breding hate and war; that war is being constantly generated today in times of so-called peace, this through our constant yielding to our desire to take advantage of our neighbors.

The attempt has been to show the close analogy between the position of the man in municipal society and of the nation in international society. We have concluded that the advancement of our knowledge of International Law, an International Law which menas something to the happiness of the world, must be based upon such a study.

In the present condition of the world's progress in the science of government, we have accepted the democratic principle as, for the present at least, the last word in government. We point out how it benefits the common man. Up till now, however, the principles of democracy have not been applied to the international field. Nations are autocratic, brooking no superior. The result has vitiated largely the good we had a right to expect to come from the growth of the democratic principle. If 
we would progress, therefore, internationally, conditions must be reversed. Instead of allowing aristocratic and antocratic law to vitiate democracy, democracy must be given its clear chance to purify the domain of what erroneously today is called International Law. Democracy can only accomplish this purification by sternly thrusting aside the suggestions of the old International Law and forming its own Law of Nitions based upon those fundamental principles of right and wrong which democracy recognizes as existing and as appropriate between man and man.

We have recognized the fact of course that the democracy of today is lame, halting and imperfect: that we are obliged as good citizens to devote onrselves to its perfection and purification; that until this takes place International Law as based upon the law of democracy of today must of necessity be imperfect. But despite this condition it is manifest enough that even an approximation in international relations to the fundamentals of democracy as today understood would bring in its train a wonderful worldwide relief to the common man. 



$$
\text { - }
$$
.

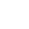

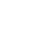

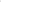


UNIVERSITY OF CALIFORNIA AT LOS ANGELES

THE UNIVERSITY LIBRARY

This book is DUE on the last date stamped below

JUL $5 \quad 195$

APR 131961. 
RI3d Democracy's international law

B. Abrahome

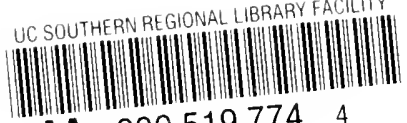

AA $000519774 \quad 4$

\section{$J \mathrm{X}$ \\ 3160 \\ R13d}


